NBER WORKING PAPER SERIES

\title{
REFERRALS: PEER SCREENING AND ENFORCEMENT IN A CONSUMER CREDIT FIELD EXPERIMENT
}

\author{
Gharad T. Bryan \\ Dean Karlan \\ Jonathan Zinman \\ Working Paper 17883 \\ http://www.nber.org/papers/w17883 \\ NATIONAL BUREAU OF ECONOMIC RESEARCH \\ 1050 Massachusetts Avenue \\ Cambridge, MA 02138 \\ March 2012
}

Previously circulated as "You Can Pick Your Friends, But You Need to Watch Them: Loan Screening and Enforcement in a Referrals Field Experiment." The authors would like to thank Manfred Kuhn and the employees of Opportunity Finance, Luke Crowley, Jon de Quidt and seminar participants at Yale, NEUDC, Warwick, Hebrew University, Stanford GSB, Wharton, The NBER summer institute and The Cambridge conference on consumer credit and bankruptcy. We would also like to thank The Bill and Melinda Gates Foundation for funding. This paper formed the third chapter of Gharad Bryan's dissertation - he would like to thank The Kauffman Foundation for financial support. All errors are, of course, our own. The views expressed herein are those of the authors and do not necessarily reflect the views of the National Bureau of Economic Research.

NBER working papers are circulated for discussion and comment purposes. They have not been peerreviewed or been subject to the review by the NBER Board of Directors that accompanies official NBER publications.

(C) 2012 by Gharad T. Bryan, Dean Karlan, and Jonathan Zinman. All rights reserved. Short sections of text, not to exceed two paragraphs, may be quoted without explicit permission provided that full credit, including $\odot$ notice, is given to the source. 
Referrals: Peer Screening and Enforcement in a Consumer Credit Field Experiment

Gharad T. Bryan, Dean Karlan, and Jonathan Zinman

NBER Working Paper No. 17883

March 2012, Revised May 2012

JEL No. C93,D12,D14,D82,O12,O16

\begin{abstract}
$\underline{\text { ABSTRACT }}$
Empirical evidence on peer intermediation lags behind many years of lending practice and a large body of theory in which lenders use peers to mitigate adverse selection and moral hazard. Using a simple referral incentive mechanism under individual liability, we develop and implement a two-stage field experiment that permits separate identification of peer screening and enforcement effects. We allow for borrower heterogeneity in both ex-ante repayment type and ex-post susceptibility to social pressure. Our key contribution is how we deal with the interaction between these two sources of asymmetric information. Our method allows us to cleanly identify selection on the likelihood of repayment, selection on the susceptibility to social pressure, and loan enforcement. We estimate peer effects on loan repayment in our setting, and find no evidence of screening (albeit with an imprecisely estimated zero) and large effects on enforcement. We then discuss the potential utility and portability of the methodological innovation, for both science and for practice.
\end{abstract}

Gharad T. Bryan

London School of Economics

Houghton Street

London WC2A 2AE

United Kingdom

g.t.bryan@1se.ac.uk

Dean Karlan

Department of Economics

Yale University

P.O. Box 208269

New Haven, CT 06520-8629

and NBER

dean.karlan@yale.edu
Jonathan Zinman

Department of Economics

Dartmouth College

314 Rockefeller Hall

Hanover, NH 03755

and NBER

jzinman@dartmouth.edu 


\title{
Referrals: Peer Screening and Enforcement in a Consumer Credit Field Experiment
}

\author{
Gharad Bryan, Dean Karlan and Jonathan Zinman*
}

April 29, 2013

\begin{abstract}
Empirical evidence on peer intermediation lags behind many years of lending practice and a large body of theory in which lenders use peers to mitigate adverse selection and moral hazard. Using a simple referral incentive mechanism under individual liability, we develop and implement a two-stage field experiment that permits separate identification of peer screening and enforcement effects. We allow for borrower heterogeneity in both ex-ante repayment type and ex-post susceptibility to social pressure. Our key contribution is how we deal with the interaction between these two sources of asymmetric information. Our method allows us to cleanly identify selection on the likelihood of repayment, selection on the susceptibility to social pressure, and loan enforcement. We estimate peer effects on loan repayment in our setting, and find no evidence of screening (albeit with an imprecisely estimated zero) and large effects on enforcement. We then discuss the potential utility and portability of the methodological innovation, for both science and for practice.
\end{abstract}

JEL Codes: C93 D12 D14 D82 O12 O16

\section{Introduction}

Economic theory assigns credit market failure a central role in explaining poverty and underdevelopment. Borrowing constraints reduce efficiency, increase inequality and can lead to poverty traps (Banerjee and Newman, 1993; Galor and Zeira, 1993). Credit rationing also appears to be empirically important. Making use of experimental or quasi-experimental supply shocks, several

\footnotetext{
*Bryan: London School of Economics and Innovations for Poverty Action, g.t.bryan@lse.ac.uk. Karlan: Yale University, M.I.T. Jameel Poverty Action Lab, Innovations for Poverty Action and NBER, dean.karlan@yale.edu. Zinman: Dartmouth College, M.I.T. Jameel Poverty Action Lab, Innovations for Poverty Action and NBER, jzinman@dartmouth.edu. The authors would like to thank Manfred Kuhn and the employees of Opportunity Finance, Luke Crowley, Jon de Quidt and seminar participants at Yale, NEUDC, Warwick, Hebrew University, Stanford GSB, Wharton, The NBER summer institute and The Cambridge conference on consumer credit and bankruptcy. We would also like to thank The Bill and Melinda Gates Foundation for funding. This paper formed the third chapter of Gharad Bryan's dissertation - he would like to thank The Kauffman Foundation for financial support. All errors are, of course, our own.
} 
recent papers estimate a large unmet demand for additional credit from consumers, microenterprises and small and medium enterprises. ${ }^{1}$ These studies, coupled with a literature that often finds high returns to capital (e.g., De Mel et al. 2008), lend credence to policy and programmatic efforts to relax borrowing constraints.

But how should one go about relaxing borrowing constraints? Information asymmetries, including ex-ante selection and ex-post incentive and enforcement problems, are often invoked as the root causes of borrowing constraints in theory (Stiglitz and Weiss, 1981) and practice (Armendáriz et al. 2010). If this is indeed the case, contracts that alleviate asymmetric information problems provide a route to greater credit market efficiency.

One popular approach to tackling asymmetric information is based on the presumption that a borrower's peers can be harnessed to provide information/screening or enforcement that is unavailable to (or more costly for) the lender. ${ }^{2}$ Peer-intermediation has been fleshed out over several hundred years of lending practice and can be seen in a range of guises including credit cooperatives, credit unions, rotating savings and credit associations, and microlenders such as the Grameen Bank. Peer intermediation has also been analyzed in a large theoretical literature on optimal mechanism design in the face of different asymmetric information problems (e.g., Varian 1990, Stiglitz 1990, Banerjee et al. 1994, Besley and Coate 1995, Ghatak 1999, Ghatak and Guinnane 1999, Rai and Sjöström 2004, and Bond and Rai 2008).

Empirical work on peer contracting has, however, lagged behind both theory and practice. Yet we need empirical tests of theories not just to inform and build on our theoretical models of credit markets, but for practical concerns to inform policy. Specifically, with more precise information on the absolute and relative importance and leverage of screening and enforcement, one can design better contracts that improve credit market efficiency. For example, if peers are able to provide high quality screening but weak enforcement, a mechanism that uses joint liability to select clients for a first loan but then moves to individual liability would harness much of the screening incentive - á la Ghatak (1999) - but minimise the possible negatives of joint liability lending such as tipping into strategic default (Besley and Coate 1995) and sub-optimal risk-taking (Fischer 2010 and Giné et al. 2011). But if enforcement is largely responsible for the success of peer schemes, then the appropriateness of peer mechanisms will decrease as ex-post enforcement is strengthened through debt collection, court action or better identification.

We formalize and implement a field experiment design that separately identifies peer screening and peer enforcement effects under weaker assumptions than previous work on asymmetric information. Our key innovations concern the interaction between hidden information and hidden action. Our framework allows borrowers to differ both with respect to their ability to repay (their repayment type) and their susceptibility to social pressure (their malleability type). Heterogeneity with respect to malleability raises the possibility of selection on malleability - that peers

\footnotetext{
${ }^{1}$ For consumers see e.g., Karlan and Zinman (2010) for microenterpretise see e.g., Banerjee et al. (2009); Karlan and Zinman (2011) and for SMEs see e.g., Banerjee and Duflo (2004).

${ }^{2}$ Throughout the paper we use the term enforcement to refer to a set of actions that might include monitoring, peer pressure, mutual insurance or direct peer assistance.
} 
select based on their ability to enforce repayment - as well as the possibility that repayment type is correlated with malleability type. We show that these issues complicate the identification of selection on repayment type - the type of selection usually associated with peer mechanisms following Ghatak (1999) - but that our experimental design overcomes these difficulties. The possibility that estimates of the extent of hidden information (that can be remedied by peer screening) depend on the extent of hidden action effects (that can be remedied by enforcement) occurs in many contract design settings. Relative to other papers that have attempted to separate selection and enforcement in a variety of settings (e.g. Karlan and Zinman 2009 and Einav et al. 2013) our experimental design allows us to identify selection without having to assume a zero correlation between ex-ante type and ex-post responsiveness to incentives. Estimates of the extent of selection on malleability are also important for contract design. Positive selection on malleability implies that the success of peer enforcement will depend on the amount of selection induced by the contract. Further, under some reasonable assumptions, selection on repayment type and selection on malleability will be substitutes, opening up the possibility that the extent of selection on repayment type will be determined by the lenders choice of enforcement technology.

Since theory, practice, and empirical work all suggest that information environments and the effectiveness of different remedies will vary across settings, ${ }^{3}$ our experiment is designed to be portable: simple, and low-cost, to implement in different settings. The hope is that that this will allow the experiment to be used to tailor contract design to the specifics of particular markets. We demonstrate the experiment in one setting in conjunction with Opportunity Finance South Africa ("Opportunity"), a consumer lender located in Kwazulu Natal and a member of the Opportunity International microfinance network.

Opportunity offered existing clients a 100 Rand (\$12) bonus for referring a new borrower who met particular criteria for Opportunity's individual liability loan. Opportunity first randomly divided referrers into one of two ex-ante incentives: referrers in the ex-ante approval group were told that they would receive the bonus if the person they referred was approved for a loan. Referrers in the ex-ante repayment group were told that they would receive the bonus if the person they referred repaid a loan on time. Referrers in the ex-ante repayment treatment had both an ex-ante incentive to refer applicants of good credit quality (both observable and unobservable to Opportunity), and an ex-post incentive to encourage repayment. Referrers in the ex-ante approval group only had an incentive to refer someone they thought would be approved for a loan.

Subsequently, Opportunity randomly surprised some referrers whose referred applications had been approved with an improvement to their bonus contract. ${ }^{4}$ Half of the referrers with the ex-ante repayment incentive were given their bonuses as soon as the loan was approved, thus removing the enforcement incentive. Half of referrers given the ex-ante approval incentive were offered an additional bonus if the referred loan was repaid, thus creating an enforcement incentive. Thus, within each of the ex-ante groups, half the referrers have an ex-post repayment

\footnotetext{
${ }^{3}$ E.g., Besley and Coate (1995) predicts that the success of peer lending will depend on the strength of "social collateral" in the community. For empirical evidence compare Giné and Karlan (2010) with Carpena et al. (2010).

${ }^{4}$ Lenders frequently contact borrowers with promotions in this market.
} 
Figure 1: $2 \times 2$ Experimental Design - Repayment Incentives ${ }^{6}$

\begin{tabular}{c|cc|c|}
\multicolumn{1}{c}{} & \multicolumn{2}{c}{ Ex-Ante Incentive } \\
\cline { 3 - 4 } \multicolumn{1}{c}{} & \multicolumn{1}{c}{ Approval } & Repayment \\
\cline { 3 - 4 } Ex-Post & Approval & No Incentive & $\begin{array}{c}\text { Screening } \\
\text { Incentive }\end{array}$ \\
\hline Incentive & Repayment & $\begin{array}{c}\text { Enforcement } \\
\text { Incentive }\end{array}$ & $\begin{array}{c}\text { Screening and } \\
\text { Enforcement } \\
\text { Incentives }\end{array}$ \\
\cline { 3 - 4 } & &
\end{tabular}

incentive and half have an ex-post approval incentive. ${ }^{5}$

The design produces four groups of referrers, each with a different combination of ex-ante and ex-post incentives, as illustrated in Figure 1. In Section 4 we provide a formal model of the referral decision and use it to show how the design can separate peer enforcement from selection on repayment type and selection on malleability. Intuitively, enforcement is measured by comparing repayment rates in different rows and selection by comparing repayment rates across columns. But selection on what? Two additional comparisons permit separate identification of selection on repayment type and selection on enforcement malleability. First, comparing repayment rates across columns only in the top row measures selection in the absence of an enforcement incentive. This comparison reveals the extent of selection on repayment type even if repayment type and malleability are correlated. Second, the design produces two estimates of the size of the enforcement effect, one with a selection incentive (comparing rows conditional on being in the right column) and one without (comparing rows conditional on being in the left column). Comparing these two estimates gives us a measure of selection on malleability.

Section 4 also uses a simple model to show when our experiment can determine whether or not referrers have information about repayment type. This is a slightly more general question - rather than asking whether the experiment induced selection, we ask whether the group of referrers has information. (Referrers might have information but not reveal it if our mechanism was ineffective.) Guided by our model, we show in the empirical section that our repayment incentive induced referrers to substitute away from referring family toward referring friends. If this substitution increases the cost of making the referral, and selection on malleability is not too strong, then we can infer that referrers at least attempted to refer high repayment types. If this attempt was unsuccessful- if we find no evidence of selection on repayment type- we infer that referrers have a (noisy) belief that they have information about repayment type, but that in practice

\footnotetext{
${ }^{5}$ The lender also contacted those referrers for whom the contract was not changed and reminded them of the existence of the contract. This was to rule out attention or signalling channels.

${ }^{6}$ Incentives refer to repayment incentives. All referrers have an incentive to refer a friend that will be approved for a loan. So, for example, No Incentive implies the there is no incentive to refer a friend that will repay, but there is an incentive to refer a friend that will be approved for a loan. We allow for a correlation between the probability of approval and the probability of repayment in interpreting the results.
} 
this information was already captured by the lender.

Results from our demonstration show strong enforcement effects. By comparing repayment rates across ex-post incentives holding the ex-ante incentive constant, we find that the small bonus (100 Rand is equal to about $2 \%$ of the average referrer's gross monthly income and $3 \%$ of the average loan size) decreased default from around $20 \%$ to $10 \%$ in most specifications. ${ }^{7}$ The magnitude of improvement in repayment performance is far above and beyond what referrers and borrowers could accomplish with side-contracting, and the improvement (and savings in collection costs) far exceeded the lender's outlays for bonuses. Indeed, the lender continues to use the repayment incentive referral post-experiment. ${ }^{8}$

We do not find strong evidence of selection effects. Comparing repayment rates across exante incentives, holding the ex-post incentive fixed, we find no evidence that peer selection on repayment type improved repayment, although this is an imprecise zero. Finally, we are unable to reject that there is no selection on malleability in our setting, although this is again an imprecisely estimated zero with confidence intervals that contain economically meaningful selection effects.

We make five main contributions relative to the existing literature. First, our experiment introduces peer influence in a simple individual liability setting where there is limited potential for complicating strategic interactions. ${ }^{9}$ This makes identification possible under weaker assumptions than required in joint liability settings. ${ }^{10}$ Second, we use a two-stage experiment to identify selection and enforcement separately, in a peer referral environment. ${ }^{11}$ Third, as discussed above, we advance the study of selection on moral hazard by developing a treatment in which there is no enforcement incentive. ${ }^{12}$ Fourth, we provide evidence on the extent of selection and enforcement effects in a particular setting, and highlight the potential for peer referral contracts to work in practice. Fifth, the portability of the experimental design can help build evidence across settings and contexts, thus leading to a more robust and thus more externally valid set of empirical results. More specifically, theories predict that peer intermediation will have effects that vary with, e.g., the lenders' ability to screen, the social environment and the heterogeneity of returns, and thus tests using this experimental design across such settings will help build a robust and empirically-validated theoretical framework.

The remainder of the paper is structured as follows. Section 2 introduces Opportunity and the South African microloan market. Section 3 provides details of the experiment. Section 4 outlines

\footnotetext{
${ }^{7}$ The emphasis of this paper is on designing contracts that encourage repayment so that the lender can relax borrowing constraints. From this perspective the lower default rate is positive. However, it is plausible that overall welfare is decreased if the social pressure is excessive. So we do not attach a welfare interpretation to any of our results.

${ }^{8}$ Besides the enforcement effect, another benefit for the lender is that referrers select on observables: referred borrowers are much more likely to be approved for a loan (55\%) than non-referred borrowers $(23 \%)$.

${ }^{9}$ See also Klonner and Rai (2010), which finds in a non-experimental setting that co-signers improve repayment performance in "organized" (intermediated) rotating savings and credit associations.

${ }^{10}$ For example, Ahlin and Townsend (2007) identifies selection effects only under the assumption that their model correctly captures the strategic situation.

${ }^{11}$ Beaman and Magruder (2012) conduct a peer referral experiment in the labor market and use it to show the presence of selection effects. They do not consider enforcement, nor the equivalent of selection on malleability.

${ }^{12}$ Recent work by Gunnsteinsson (2012) on crop insurance provides an example of how non-enforcement incentives can be applied in other product markets.
} 
a simple model of the referrer's decision process, highlighting the conditions under which our experiment separately identifies enforcement and selection. Section 5 provides some summary statistics and discusses the integrity of the randomization. Section 6 provides our main results. Section 7 discusses a few alternative explanations of the data and Section 8 concludes.

\section{Market and Lender Overview}

Our cooperating lender is a new entrant to the South African consumer microloan market. Opportunity Finance South Africa (Opportunity) is a for-profit, wholly-owned subsidiary of Opportunity International, which has 1.26 million micro-loan customers across 24 different countries. Opportunity operates in the state of Kwazulu Natal, South Africa, and expanded from one branch in Pietermaritzburg to 5 branches across the state during our study period (February 2008 through July 2009). Opportunity offers small, high-interest, uncollateralised debt with a fixed monthly repayment amount. Loans made during our study period averaged around 3500R (\$US400), with a modal (mean) duration of 9 (10) months, and a modal (mean) monthly percentage rate of $5 \%$ $(4.1 \%)$. There is a competitive market for these loans in Kwazulu Natal (see Karlan and Zinman 2010 for a description of a different lender in this market).

Opportunity underwrites applications using a combination of internal and external credit scores (South Africa has well-functioning credit bureaus). A necessary condition for getting a loan is a documented, steady, salaried job. The loans are not tied to a specific purpose, but borrowers are asked the purpose of the loan and most report needing the money for paying school fees for their children, attending/organizing a funeral, or purchasing a durable.

\section{The Experiment}

From February 2008 through July 2009, Opportunity offered each individual approved for a loan the opportunity to participate in its new "Refer-A-Friend" program. Individuals could participate in the program only once. Referrers received a referral card, which they could give to a friend (the referred). The referred earned R40 (\$US5) if she brought in the card and was approved for a loan. The referrer could earn R100 (\$US12) ${ }^{13}$ for referring someone who was subsequently approved for and/or repaid a loan, depending on the referrer's incentive contract.

Opportunity first randomly assigned referrers to one of two ex-ante incentive contracts, corresponding to two different referral cards. Referrers given an ex-ante approval incentive would be paid only if the referred was approved for a loan. Referrers given the ex-ante repayment incentive would be paid only if the referred successfully repaid a loan. ${ }^{14}$ Figure ?? shows examples of the

\footnotetext{
${ }^{13}$ The bonus for the referrer was initially R60 but was changed to R100 in July 2008 at the request of the lender. The inclusion of this as a control makes no difference in any of our results.

${ }^{14}$ Successful repayment was defined as having no money owing on the date of maturity of the loan.
} 
referral cards, the top card was given to referrers in the ex-ante approval group and the bottom card to those in the ex-ante repayment group.

Figure 2: Referral Cards
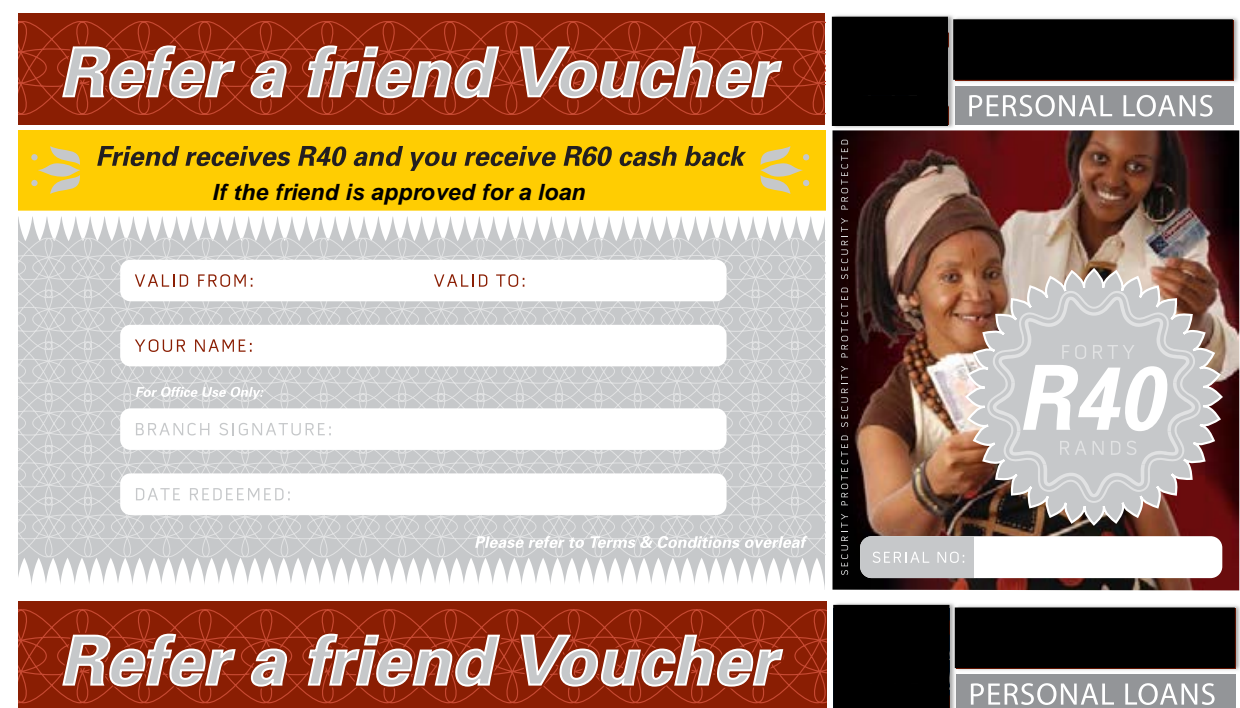

Friend receives $R 40$ and you receive $R 60$ cash back If the friend successfully repays a loan
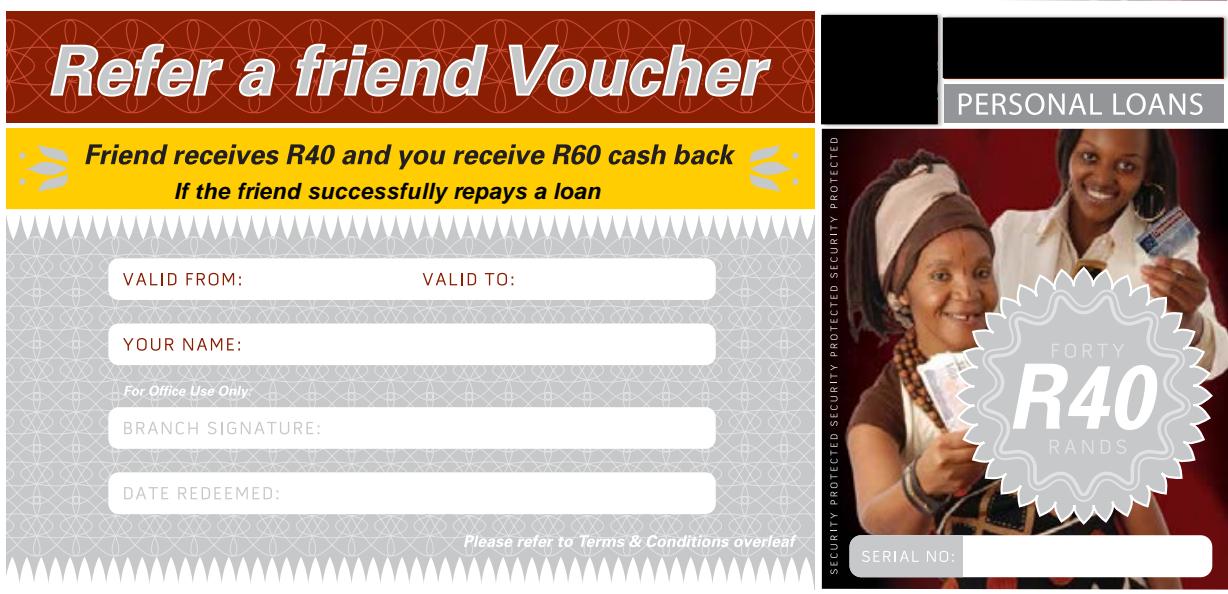

Among the set of referrers whose referred friends were approved for a loan, Opportunity randomly selected half to be surprised with an ex-post incentive change.

Among referrers who had been given the ex-ante approval incentive, half were assigned to receive an additional ex-post repayment incentive. Opportunity phoned referrers in the additionalincentive arm and told them that, in addition to the R100 approval bonus, they would receive an additional R100 if the referred repaid the loan. Opportunity also phoned the other half of referrers in the ex-ante approval incentive group- those who did not get the additional ex-post repayment incentive- with a remninder to pick up their R100 bonus. The phone call did not provide any new information on the incentive contract to this second arm, but we wanted every referrer to get a call from Opportunity in case the personalized contact from the lender had some effect.

Among referrers who had been given the ex-ante repayment incentive, half of the referrers 
were assigned to have the ex-post repayment incentive removed. Opportunity phoned referrers in this arm, told them that they would be paid R100 now instead of conditional on loan repayment, and explained that this was the extent of the referrer's bonus eligibility (e.g., that the referrer would not receive an additional R100 if the loan was repaid). The other half of referrers who had been given the ex-ante repayment incentive were assigned to continue with an ex-post repayment incentive. Opportunity phoned these referrers with a reminder that they would receive a bonus if the loan was repaid.

Figure 1 summarizes the randomization and the incentives that the referrers face. Intuitively, any effect of peer screening can be identified by comparing the arms with and without an ex-ante repayment incentive, holding constant the ex-post incentive. Similarly, any effect of peer enforcement can be identified by comparing the arms with and without an ex-post repayment incentive, holding constant the ex-ante incentive.Two additional comparisons permit separate identification of selection on repayment type and selection on enforcement malleability. First, comparing repayment rates across columns only in the top row measures selection in the absence of an enforcement incentive. This comparison reveals the extent of selection on repayment type even if repayment type and malleability are correlated. Second, the design produces two estimates of the size of the enforcement effect, one with a selection incentive (comparing rows conditional on being in the right column) and one without (comparing rows conditional on being in the left column). Comparing these two estimates gives us a measure of selection on malleability.

\section{Identification}

In this section we provide a stylised model of the referral decision to help clarify the interpretation of our experiment. We provide the simplest model possible to discuss the interaction between selection on repayment type, selection on malleability, and enforcement. We outline the basic model in Section 4.1. Section 4.2 then relates the model to the data collected in the experiment. Section 4.3 interprets the different repayment rates induced by the experiment, giving formal definitions of selection on repayment type and selection on malleability and then discussing how these are identified by the experiment. Section 4.4 analyses the extent to which the experiment allows us to determine whether referrers have information about their peers' repayment types.

\subsection{The Referral Decision}

A market consists of $N$ potential borrowers (referreds), each of whom is characterised by four parameters:

1. $\theta \in\left\{\theta^{L}, \theta^{H}\right\}:$ a repayment type;

2. $\sigma \in\left\{\sigma^{L}, \sigma^{H}\right\}$ : a malleability type;

3. $\gamma \in\left\{\gamma^{L}, \gamma^{H}\right\}$ : the probability that the individual is approved for a loan; and 
4. $\lambda \in(0, \bar{\lambda}]$ : the net cost of recruiting the individual to the referral scheme, including all social and search costs and/or benefits, but excluding the referral bonus.

We assume that these characteristics are drawn from a population distribution $F$, and allow for characteristics to be correlated. In particular, it may be that repayment type is correlated with malleability; we discuss below how this would affect identification. We concentrate on the case with binary types for ease of exposition. ${ }^{15}$

We assume that referrer $j$ knows the cost of referral $\lambda_{i j}{ }^{16}$ and holds beliefs $\left(\hat{\theta}_{i j}, \hat{\sigma}_{i j}, \hat{\gamma}_{i j}\right)$ about each potential referred $i$. We further assume that each of these beliefs is binary. So, for example, $\hat{\theta} \in\left\{\hat{\theta}^{L}, \hat{\theta}^{H}\right\}$ with the interpretation that $\hat{\theta}_{i j}=\hat{\theta}^{H}$ implies that referrer $j$ believes potential referred $i$ to be a high repayment type.

The timing of the referral decision is as follows:

1. Referrer $j$ chooses a referred $i$ and pays a $\operatorname{cost} \lambda_{i j}$ (she may also choose not to make a referral);

2. The referred is approved for a loan with probability $\gamma_{i}$;

3. The referrer applies social pressure $e$ to encourage repayment and incurs $\operatorname{cost} c(e)$, where $c$ is a strictly convex cost function;

4. The loan is repaid with probability $\theta_{i}+\sigma_{i j} e^{17}$

We assume that $\left\{\theta^{H}, \theta^{L}\right\}$ and $\left\{\sigma^{H}, \sigma^{L}\right\}$ are such that the probability of repayment always lies between zero and one given an optimal effort choice. We could allow for a more complicated repayment function without altering our discussion. An advantage of the linear form is that $\sigma$ encodes all the information needed to determine the impact of enforcement effort.

In making the referral decision, a referrer takes into account the possibility that she will exert pressure on the referred to repay the loan. We therefore consider the decision backward, first analysing the effort decision and then returning to the referral decision.

Consider first the effort decision. If the referrer is in the ex-ante approval treatment she knows she will exert no effort. If the referrer is in the ex-ante repayment treatment she foresees choosing her level of effort to solve

$$
\max _{e}\left\{B_{R}(\hat{\theta}+\hat{\sigma} e)-c(e)\right\}
$$

where $B_{R}$ is the bonus payment in the repayment treatment. We denote the unique maximiser $e^{*}(\hat{\sigma})$ which depends on $\hat{\theta}$ only through a correlation between $\hat{\sigma}$ and $\hat{\theta}$. For a borrower of type $(\theta, \sigma)$ perceived to be of type $(\hat{\theta}, \hat{\sigma})$ the repayment probability is $\theta+\sigma e^{*}(\hat{\sigma})$.

\footnotetext{
${ }^{15}$ Allowing for more types does not alter the thrust of the arguments. However, we comment in the text where allowing for a richer type space would lead to a slightly different interpretation.

${ }^{16}$ This last assumption seems reasonable given that we assume the cost is paid prior to the referral. Beliefs could be derived from a more primitive model in which the referrer has a prior belief about types, receives a signal and uses Bayes' rule to form the beliefs $\left(\hat{\theta}_{i j}, \hat{\sigma}_{i j}, \hat{\gamma}_{i j}\right)$.

${ }^{17} \sigma$ is potentially specific to the referrer-referred match, and we allow for that in our notation.
} 
Now consider the referral decision. Given the effort decision discussed above, referrer $j$ in the ex-ante approval group chooses who to refer by solving

$$
U_{j}(A) \equiv \max _{i \in N_{j}}\left\{\hat{\gamma}_{i} B_{A}-\lambda_{i j}\right\}
$$

where $B_{A}$ is the bonus paid in approval treatment. Because the bonus in the ex-ante approval treatment is expected to arrive earlier in time (immediately after approval) $B_{A} \geq B_{R}$. In the ex-ante repayment group referrer $j$ solves

$$
U_{j}(R) \equiv \max _{i \in N_{j}}\left\{\hat{\gamma}_{i}\left(B_{R}\left(\hat{\theta}+\hat{\sigma} e^{*}(\hat{\sigma})\right)-c\left(e^{*}(\hat{\sigma})\right)\right)-\lambda_{i j}\right\} .
$$

Equation (2) makes clear that the selection decision depends on both the belief about repayment type and the belief about malleability. Finally, the model is completed by noting that referrer $j$ makes a referral in the ex-ante repayment treatment if $U_{j}(R)>0$ and in the approval treatment if $U_{j}(A)>0$.

\subsection{Map from Model to Data}

Our analysis focuses on the repayment behaviour of individuals referred in the different treatments. We denote the ex-ante treatment assignment with a lower case letter and the ex-post assignment with an upper case letter. So, for example, $E(\lambda \mid a R)$ is the expectation of $\lambda$ conditional on the referrer being in the ex-ante approval group and ex-post repayment group, while $E(\lambda \mid a)$ is the expectation of $\lambda$ conditional on being in the ex-ante approval group, unconditional on ex-post treatment assignment.

We have two potential measures of selection. Define $S(A)$ as the difference in repayment probabilities across ex-ante treatments conditional on being in the ex-post approval treatment (where there is no enforcement incentive). $S(A)$ is given by the expression

$$
S(A)=E(\theta \mid r A \& a p p)-E(\theta \mid a A \& a p p)
$$

where app implies that the observation is conditional on the referred individual being approved for a loan, and expectations are taken over the population of referrers. We can also define define $S(R)$ as the same comparison conditional on being in the ex-post repayment treatment:

$$
S(R)=E\left(\theta+\sigma e^{*}(\hat{\sigma}) \mid r R \& a p p\right)-E\left(\theta+\sigma e^{*}(\hat{\sigma}) \mid a R \& a p p\right) .
$$

We also have two potential measures of enforcement. We define

$$
N(r)=E\left(\theta+\sigma e^{*}(\hat{\sigma}) \mid r R \& a p p\right)-E(\theta \mid r A \& a p p)
$$

as the different in repayment rates across enforcement treatments conditional on the ex-ante re- 
payment incentive. We can also define the equivalent measure conditional on being in the ex-ante approval treatment

$$
N(a)=E\left(\theta+\sigma e^{*}(\hat{\sigma}) \mid a R \& a p p\right)-E(\theta \mid a A \& a p p) .
$$

\subsection{Identifying Selection and Enforcement}

The identification of enforcement effects is straightforward if the ex-post treatment does not affect the referral or approval decision. This is a reasonable assumption, and a testable one (Section 5.2), given that the referral and approval decisions occur without the referrer or lender staff knowing the ex-post treatment assignment. Under this assumption, repayment type cancels out of the expressions for both $N(a)$ and $N(r)$ so that $N(a)=E\left(\sigma e^{*}(\hat{\sigma}) \mid a R\right.$ \& app) and $N(r)=E\left(\sigma e^{*}(\hat{\sigma}) \mid r R \& a p p\right)$. Therefore each of the expressions provides an estimate of the extent to which social pressure can encourage loan repayment: our experiment generates two estimates of the peer enforcement effect. These estimates may differ if perceived and actual malleability differ across the ex-ante treatments.

We now turn to identification of selection, focusing first on repayment type and then on malleability.

Definition 1. [Selection on Repayment Type] We say that our repayment incentive induced selection on repayment type if

$$
E(\theta \mid r \& a p p)>E(\theta \mid a \& a p p) .
$$

That is, on average, the set of clients referred under the ex-ante repayment incentive, and subsequently approved for a loan, are more likely to repay than those referred under the ex-ante approval incentive.

We use average repayment rates because they are relevant to the firm's profitability and, therefore, its contract design choice. We condition on approval because the approval decision is necessary in credit (and insurance, and labor) markets. A definition of selection on repayment type that was not conditional on approval may seem more general, but would not be useful if the lender can't design an approval process that allows higher referred types to be approved. ${ }^{18}$ Given our definition, the comparison $S(A)$ defined above provides clean identification of the extent of selection on repayment type.

It is important to note that $S(R)$ does not cleanly identify selection on repayment type because it includes the effect of social pressure. If the effectiveness or extent of social pressure depends on the repayment type (in our model this would occur through a correlation between repayment type and malleability type) then $S(R)$ could over- or under-estimate the extent of selection on repayment type. Moreover, theory does not pin down the sign of the correlation between repayment type and malleability. One intuition suggests that there is less scope for social pressure on

\footnotetext{
${ }^{18}$ The extent of selection on repayment type under our definition will be proportional to the extent of selection on repayment type under the unconditional definition so long as we are willing to assume that the probability of approval is strictly increasing in repayment type. This seems like a reasonable assumption in most settings.
} 
those who are predisposed to repay: $\operatorname{corr}(\hat{\sigma}, \hat{\theta})<0$ and $\operatorname{corr}(\sigma, \hat{\theta})<0$. So in this case high types would be less malleable. Social pressure might even be counterproductive if high repayment types are intrinsically motivated and external pressure crowds out intrinsic motivation (e.g. Gneezy and Rustichini 2000, Benabou and Tirole 2003 \& Besley and Ghatak 2005). A second intuition, however, suggests that high types will be more malleable; e.g., they already care the most about repaying and hence will also care most about how they are viewed by their peers. If this is the case we would expect that $\operatorname{corr}(\hat{\sigma}, \hat{\theta})>0$ and $\operatorname{corr}(\sigma, \hat{\theta})>0 .{ }^{19}$

We refer to this issue as the comparability problem because $S(R)$ does not provide an applesto-apples comparison: the two groups potentially differ in the extent of social pressure and malleability. The comparability problem occurs in settings where there is both hidden information, and hidden action that could depend on the extent of hidden information.

We now consider selection on malleability.

Definition 2. [Selection on Malleability] We say that our incentive induced positive (negative) selection on malleability if

$$
E\left(\sigma e^{*}(\hat{\sigma}) \mid r R \& a p p\right)>(<) E\left(\sigma e^{*}(\hat{\sigma}) \mid a R \& a p p\right) .
$$

That is, on average the set of clients referred under the ex-ante repayment incentive, and subsequently approved for a loan, are more (less) susceptible to the chosen social pressure of their referrer than those referred under the ex-ante approval incentive.

As above, we condition on approval and look at average repayment rates as we believe that this is the most appropriate measure when considering how to design contracts. We further condition on the optimal choice of social pressure in the ex-post repayment treatment. An alternative would be to define positive (negative) selection on malleability to be

$$
E(\sigma \mid r \& a p p)>(<) E(\sigma \mid a \& a p p)
$$

Again, this may seem a more natural definition, but a more malleable set of referrers is not helpful to the lender if the referrers do not in fact put the appropriate pressure on these referrers.

Again assuming that the ex-post treatment does not affect the referral or approval decision we have

$$
S(R)-S(A)=E\left(\sigma e^{*}(\hat{\sigma}) \mid r R \& a p p\right)-E\left(\sigma e^{*}(\hat{\sigma}) \mid a R \& a p p\right) .
$$

Therefore, $S(R)-S(A)>(<) 0$ implies positive (negative) selection on malleability. ${ }^{20}$

\footnotetext{
${ }^{19}$ In the more familiar setting of moral hazard and adverse selection in the credit market, Karlan and Zinman (2009) provide a simple model that implies high types put more effort into ensuring project success. If that model is true, correlation between hidden information and the extent of hidden action would tend to lead to an underestimate of the extent of selection on risk type. Even in that case, however, it is possible to tweak the simple model and reverse the comparative static. The extent and direction of these interaction effects is, therefore, an empirical matter.

${ }^{20}$ There is a meaningful distinction between intentional and incidental selection on malleability if referrers are not forward-looking or do not actually have a good signal on malleability type. Although these contingencies seems unlikely to arise,we note two points. First, it is the possiblity of incidental selection on malleability-in particular of high repayment types being less malleable- that leads to the possibility of negative selection on malleability. Second, observing $S(A)<0$ and $S(R)>0$ is only possible if there is positive intentional selection on malleability, and if selection on repayment type
} 


\subsection{Do Referrers Have Information?}

The above discussion shows what is identified by the the experiment. In this section we argue that we can use the experiment to understand whether referrers have information regarding repayment types. This is a more general question than asking whether there is selection on repayment type. For example, if we see no selection on repayment type it may be that referrers have information, but the experiment did not lead them to reveal that information. We will argue in this section and the empirical work that follows that the experiment did lead referrers to attempt to select high repayment types, but that this selection was (subject to power considerations) unsuccessful. We interpret this as evidence that referrers in fact have no useful information - at least that can be extracted with incentives of the size we use. From a contract design perspective, this means that our experiment can be useful in ruling out a whole class of mechanisms, rather than just implying that our particular example is not effective in inducing selection.

Definition 3. [Referrer Knowledge] We say that referrers have information about repayment type if

$$
E\left(\theta \mid \hat{\theta}=\hat{\theta}^{H} \& a p p\right)>E\left(\theta \mid \hat{\theta}=\hat{\theta}^{L} \& a p p\right)
$$

As with the definitions of selection above, this statement is conditional on loan approval: we are interested in whether referrers have information that predicts repayment above and beyond the information that the lender observes.

Inferring whether referrers have information can, but need not, be straightforward. If $S(A)>$ 0 it must be that the referrers have information about repayment type. But if $S(A) \leq 0$ it is not immediately clear whether referrers have information. It may be that referrers have information, but that they have not been induced to reveal it. For example, our model allows for the possibility that referrers believe approval types $\hat{\gamma}$ and repayment types $\hat{\theta}$ to be highly correlated. In this case there may be no differential incentive to refer high types in the ex-ante repayment treatment. Alternatively, because $B_{A} \geq B_{R}$ referrers in the ex-ante approval treatment may be willing to pay a higher cost $\lambda$ to make a referral. If $\lambda$ is correlated with repayment type we may even see $S(A)<0$, but this would not necessarily show a lack of information. Finally, it could just be that referrers tend to only have one potential referred.

We argue that if $E(\lambda \mid r)>E(\lambda \mid a), S(A)=0, S(R)=S(A)$ and $\hat{\sigma}$ is positively correlated with $\sigma$, then we can infer that referrers do not have information. To see this note that we can write

$$
\begin{gathered}
S(A) \equiv \operatorname{Pr}\left(\hat{\theta}=\hat{\theta}^{H} \mid r\right) E\left(\theta \mid \hat{\theta}^{H} \& \mathrm{app}\right)+\left(1-\operatorname{Pr}\left(\hat{\theta}=\hat{\theta}^{H} \mid r\right)\right) E\left(\theta \mid \hat{\theta}^{L} \& \mathrm{app}\right) \\
-\left(\operatorname{Pr}\left(\hat{\theta}=\hat{\theta}^{H} \mid a\right) E\left(\theta \mid \hat{\theta}^{H} \& \mathrm{app}\right)+\left(1-\operatorname{Pr}\left(\hat{\theta}=\hat{\theta}^{H} \mid a\right)\right) E\left(\theta \mid \hat{\theta}^{L} \& \mathrm{app}\right)\right) .
\end{gathered}
$$

Consequently, if the experiment induces selection in the sense that

$$
\operatorname{Pr}\left(\hat{\theta}=\hat{\theta}^{H} \mid r\right)>\operatorname{Pr}\left(\hat{\theta}=\hat{\theta}^{H} \mid a\right),
$$

(SELECTION)

and selection on malleability are substitutes. 
then $S(A)=0$ implies that referrers have no information. To complete the argument we need to show that $E(\lambda \mid r)>E(\lambda \mid a)$ and $S(R)-S(A)=0$ imply SELECTION.

The condition $E(\lambda \mid r)>E(\lambda \mid a)$, combined with (1) and (2), implies that

$$
E\left(\hat{\gamma}\left(B_{R}\left(\hat{\theta}+\sigma e^{*}(\hat{\sigma})\right)-c\left(e^{*}(\hat{\sigma})\right)\right) \mid r\right)>E\left(\hat{\gamma}\left(B_{R}\left(\hat{\theta}+\sigma e^{*}(\hat{\sigma})\right)-c\left(e^{*}(\hat{\sigma})\right)\right) \mid a\right) .
$$

This follows because there must be some expected return to making a high cost referral. Condition (4), combined with the assumption that $c$ is strictly convex, then implies that $E\left(\hat{\theta}+\sigma e^{*}(\sigma) \mid r\right)>$ $E\left(\hat{\theta}+\sigma e^{*}(\sigma) \mid a\right)$ : that the ex-ante incentive induced selection on the probability of repayment conditional on anticipated effort. To complete the argument, observe that if $S(R)=S(A)$ then $E\left(\hat{\theta}+\sigma e^{*}(\sigma) \mid r\right)>E\left(\hat{\theta}+\sigma e^{*}(\sigma) \mid a\right)$ implies $E(\hat{\theta} \mid r)>E(\hat{\theta} \mid a)$ so long as we are willing to make the weak assumption that $\hat{\sigma}$ is positively correlated with $\sigma$ : that those perceived to be more malleable are, in reality, more malleable.

Finally, it is worth noting that our restriction to two repayment types may be restrictive in the case where $S(A)=0$. Our experiment provides a limited incentive $\left(B_{R}\right)$ to refer a good repayment type. It may be that this incentive induces SELECTION within a set of low-cost referreds, and that a larger incentive would induce selection across a larger group of potential referreds. For example, it may be that the referrers know people who are high repayment types, but that it is very costly to contact them and make the referral.

\section{Data}

\subsection{Summary Statistics}

Table 1 provides a summary of the characteristics of potential referrers over the period in which the experiment was run.

\subsection{Integrity of the Randomization}

Opportunity handed out 4408 referral cards to potential referrers- borrowers approved for new loans-during the study period. ${ }^{21}$ Table 2 presents regressions of treatment assignment on referrer characteristics at baseline. If the randomization is valid, we would expect these characteristics to be uncorrelated with treatment. In all cases an F-test of the restriction that the coefficients are jointly zero fails to reject at the usual significance levels. Further, most individual coefficients are not statistically different from zero and the total number of significant coefficients is in line with what we would expect to see by chance. Below we also show that our treatment effect estimates are robust to including controls for referrer baseline characteristics.

\footnotetext{
${ }^{21}$ Referred clients were not eligible for a card. This restriction was aimed to reduce learning about the treatments among potential referreds.
} 
Table 1: Demographic Variables of all Borrowers During Experiment

\begin{tabular}{lccc}
\hline & Mean & Median & Std Dev \\
\cline { 2 - 4 } Female & 0.418 & - & 0.493 \\
Age & 37.789 & 36.000 & 10.785 \\
High School Education & 0.637 & - & 0.481 \\
$\begin{array}{l}\text { Disposable Income } \\
\text { Requested Amount }\end{array}$ & 1753 & 1265 & 1703 \\
$\begin{array}{l}\text { Requested Term } \\
\text { (Months) }\end{array}$ & 5049 & 3000 & 6615 \\
$N$ & 10.743 & 9 & 6.265 \\
\hline \hline
\end{tabular}

Disposable income is income remaining after rent, debt repayments and recurring obligations. An individual has a high school education if they have matriculated or gone on to tertiary education.

Of the 4408 cards that were handed out, 430 were returned and 245 of these referred clients were approved for a loan. The surprise nature of the second randomization (i.e. the change in ex-post incentives) provides another opportunity to check the integrity of the experimental implementation. Because the second-stage assignments were not known to potential referrers exante (nor to Opportunity staff members delivering referral cards), baseline characteristics of those referred and approved for a loan ${ }^{22}$ should not differ within the ex-ante treatment groups. ${ }^{23}$ Table 3 presents tests this hypothesis from regressions where the outcome variable is being assigned to the ex-post repayment incentive.

Within the group given the ex-ante approval incentive (Table 3 Column 1), the F-test shows that the baseline coefficients do not significantly predict assignment to treatment in the joint test. Among the individual tests, only one of the sixteen variables is significant, which is about what one would expect to happen by chance.

Within the group given the ex-ante repayment incentive (Column 2), a higher application score (i.e., internal credit score) significantly predicts assignment to the ex-post approval group. Given that application score is a key measure of the observed credit quality of the applicant, this is troubling. It turns out that Opportunity changed its application score in May 2009 (before this time, scores are out of 200, while after they are out of 800). Only 12 referred clients from the exante repayment group were approved for loans after the change, with 9 coming from the ex-post

\footnotetext{
${ }^{22}$ Results are similar if we do not condition on approval, and instead consider the full sample of 430 referreds.

${ }^{23}$ Comparison across the ex-ante incentive groups are, however, endogenous. That is, we cannot compare characteristics of those in the ex-ante approval groups to those in the ex-ante repayment groups because the experiment aims to generate difference in these characteristics.
} 
Table 2: Testing The Balance of Referrer Characteristics Across Treatments: OLS

\begin{tabular}{|c|c|c|c|c|}
\hline \multirow{2}{*}{$\begin{array}{l}\text { Ex-Ante Incentive } \\
\text { Ex-Post Incentive }\end{array}$} & \multicolumn{2}{|c|}{ Approval } & \multicolumn{2}{|c|}{ Repayment } \\
\hline & Approval & Repayment & Approval & Repayment \\
\hline Female & $\begin{array}{l}-0.006 \\
(0.014)\end{array}$ & $\begin{array}{l}0.008 \\
(0.014)\end{array}$ & $\begin{array}{c}0.005 \\
(0.014)\end{array}$ & $\begin{array}{l}-0.008 \\
(0.014)\end{array}$ \\
\hline Age & $\begin{array}{l}0.000 \\
(0.001)\end{array}$ & $\begin{array}{l}-0.001 \\
(0.001)\end{array}$ & $\begin{array}{l}0.000 \\
(0.001)\end{array}$ & $\begin{array}{l}0.000 \\
(0.001)\end{array}$ \\
\hline High School Education & $\begin{array}{l}-0.027 \\
(0.023)\end{array}$ & $\begin{array}{l}0.027 \\
(0.023)\end{array}$ & $\begin{array}{l}-0.007 \\
(0.023)\end{array}$ & $\begin{array}{l}0.008 \\
(0.023)\end{array}$ \\
\hline Salary Earner & $\begin{array}{l}-0.004 \\
(0.016)\end{array}$ & $\begin{array}{l}0.022 \\
(0.016)\end{array}$ & $\begin{array}{l}-0.016 \\
(0.016)\end{array}$ & $\begin{array}{l}-0.003 \\
(0.016)\end{array}$ \\
\hline $\begin{array}{l}\text { Disposable Income } \\
\text { (Thousands of Rand) }\end{array}$ & $\begin{array}{l}-0.003 \\
(0.004)\end{array}$ & $\begin{array}{l}-0.006 \\
(0.004)\end{array}$ & $\begin{array}{l}0.010^{*} \\
(0.004)\end{array}$ & $\begin{array}{l}-0.001 \\
(0.004)\end{array}$ \\
\hline Application Score & $\begin{array}{c}0.000 \\
(0.000)\end{array}$ & $\begin{array}{l}0.000 \\
(0.000)\end{array}$ & $\begin{array}{l}0.000 \\
(0.000)\end{array}$ & $\begin{array}{l}0.000 \\
(0.000)\end{array}$ \\
\hline ITC Score & $\begin{array}{l}0.000 \\
(0.000)\end{array}$ & $\begin{array}{l}0.000 \\
(0.000)\end{array}$ & $\begin{array}{l}0.000 \\
(0.000)\end{array}$ & $\begin{array}{l}0.000 \\
(0.000)\end{array}$ \\
\hline ITC Score Missing & $\begin{array}{c}0.072 \\
(0.109)\end{array}$ & $\begin{array}{c}0.039 \\
(0.109)\end{array}$ & $\begin{array}{l}-0.058 \\
(0.109)\end{array}$ & $\begin{array}{l}-0.053 \\
(0.110)\end{array}$ \\
\hline $\begin{array}{l}\text { Requested Amount } \\
\text { (Thousands of Rand) }\end{array}$ & $\begin{array}{l}-0.001 \\
(0.002)\end{array}$ & $\begin{array}{l}0.004^{*} \\
(0.002)\end{array}$ & $\begin{array}{l}-0.004^{*} \\
(0.002)\end{array}$ & $\begin{array}{c}0.000 \\
(0.002)\end{array}$ \\
\hline $\begin{array}{l}\text { Requested Term } \\
\text { (Months) }\end{array}$ & $\begin{array}{c}0.002 \\
(0.002)\end{array}$ & $\begin{array}{l}-0.004^{*} \\
(0.002)\end{array}$ & $\begin{array}{c}0.002 \\
(0.002)\end{array}$ & $\begin{array}{l}0.000 \\
(0.002)\end{array}$ \\
\hline Government Worker & $\begin{array}{c}0.005 \\
(0.031)\end{array}$ & $\begin{array}{l}-0.002 \\
(0.031)\end{array}$ & $\begin{array}{c}0.022 \\
(0.032)\end{array}$ & $\begin{array}{l}-0.025 \\
(0.032)\end{array}$ \\
\hline Cleaner/Builder/Miner & $\begin{array}{l}0.010 \\
(0.031)\end{array}$ & $\begin{array}{l}-0.006 \\
(0.031)\end{array}$ & $\begin{array}{l}0.007 \\
(0.031)\end{array}$ & $\begin{array}{l}-0.011 \\
(0.031)\end{array}$ \\
\hline Security /Mining/Transport & $\begin{array}{c}0.021 \\
(0.033)\end{array}$ & $\begin{array}{l}-0.004 \\
(0.033)\end{array}$ & $\begin{array}{l}0.020 \\
(0.033)\end{array}$ & $\begin{array}{l}-0.037 \\
(0.033)\end{array}$ \\
\hline Retail Worker & $\begin{array}{c}-0.002 \\
(0.031)\end{array}$ & $\begin{array}{l}0.008 \\
(0.031)\end{array}$ & $\begin{array}{c}0.003 \\
(0.032)\end{array}$ & $\begin{array}{l}-0.009 \\
(0.032)\end{array}$ \\
\hline IT / Financial Woker & $\begin{array}{c}0.010 \\
(0.035)\end{array}$ & $\begin{array}{l}-0.025 \\
(0.035)\end{array}$ & $\begin{array}{l}0.014 \\
(0.035)\end{array}$ & $\begin{array}{c}0.001 \\
(0.035)\end{array}$ \\
\hline Agriculture/Manufacturing & $\begin{array}{c}0.008 \\
-0.029\end{array}$ & $\begin{array}{l}-0.005 \\
-0.029\end{array}$ & $\begin{array}{l}0.027 \\
-0.029\end{array}$ & $\begin{array}{l}-0.030 \\
-0.029\end{array}$ \\
\hline Constant & $\begin{array}{c}0.189 \\
(0.118)\end{array}$ & $\begin{array}{c}0.224 \\
(0.118)\end{array}$ & $\begin{array}{l}0.273^{* *} \\
(0.119)\end{array}$ & $\begin{array}{l}0.315^{*} \\
(0.120)\end{array}$ \\
\hline $\begin{array}{l}F \text {-test of joint significance } \\
p \text {-value of } F \text {-test }\end{array}$ & $\begin{array}{l}0.560 \\
0.916\end{array}$ & $\begin{array}{l}0.930 \\
0.533\end{array}$ & $\begin{array}{l}0.810 \\
0.679\end{array}$ & $\begin{array}{l}0.440 \\
0.971\end{array}$ \\
\hline$N$ & 4408 & 4408 & 4408 & 4408 \\
\hline
\end{tabular}

${ }^{* * *} \Rightarrow p<0.01,{ }^{* *} \Rightarrow p<0.05,{ }^{*} \Rightarrow p<0.1$. Each column represents a separate OLS regression where the LHS variable is assignment to the particular treatment. Education is a dummy variable taking on value 1 if the referrer has matriculated. Application score is an internal credit score. ITC score is external credit score. Salary monthly is a dummy variable taking value 1 if the client receives his or her salary monthly. 
approval group. This is not out of line with what we would expect from random arrival times, but it does create a problem in testing orthogonality. Columns 3 and 4 of Table 3 take two approaches. Column 3 omits the application score, and the $p$-value for the $F$-test of joint significance rises to 0.326 (from 0.077 in Column 2). Column 4 drops the 12 post-change observations (so the sample size falls from 120 to 108), and the p-value is 0.478 . We also note that the ITC (external) credit score- which is provided by a credit bureau and is another key predictor of credit worthiness- is never predictive of treatment status.

Overall it seems that the randomization was succesful. We also show below that our results are not sensitive to including these baseline characteristics as controls. ${ }^{24}$

\section{Results}

\subsection{Who Refers and Who Gets Referred?}

430 of 4408 , or $10 \%$, of eligible clients made a referral. Making a referral is not correlated with the ex-ante incentive: a regression of the referral rate on a dummy for ex-ante treatment gives a coefficient of -0.002 with a standard error of 0.040 . This suggests that the higher net present value of the bonus in the ex-ante approval group did not loom large in the referrers' calculations and induce greater search. And it bodes well for using the assumption that $E(\lambda \mid a)<E(\lambda \mid r)$ to help identify whether referrers have information.

We also collected data on the relationship between referrers and referreds. Specifically, the lender asked the referred "How do you know the person that gave you the voucher?" Most people answered that the referrer was a relative or work colleague. A small number answered church. Table 4 shows the impact of the ex-ante repayment incentive (being in the ex-ante repayment group) on the probability of referring a relative or a work colleague. The table shows that the selection incentive leads referrers to substitute away from relatives toward those they know through church and their work colleagues - those with the ex-ante repayment incentive are $10 \%$ less likely to refer a relative .

We argue that this finding implies that $E(\lambda \mid r)>E(\lambda \mid a)$. First, we believe that it is intuitive that colleagues are more costly to refer than family members. This is both because colleagues may be harder to approach and because there may be a positive obligation to refer family members given the R40 bonus given to the referred. Second, Beaman and Magruder (2012) find similar substitution toward referring colleagues in a labor market experiment in India. Their experiment also documents that referred colleagues are more productive workers than referred family members, which would only occur if colleagues are indeed more costly to refer. Consequently, following our analysis in Section 4.4, if we can now show that $S(R)=S(A)$ and $S(A)=0$ we will infer that referrers have no information.

\footnotetext{
${ }^{24}$ We can only control for these differences when studying the enforcement question; when we consider selection, referred characteristics are endogenous.
} 
Table 3: Testing The Balance of Referred Characteristics Across Ex-Post Treatments. Dependent Variables is Assignment to Ex-Post Repayment Incentive: OLS

\begin{tabular}{|c|c|c|c|c|}
\hline \multirow{3}{*}{$\begin{array}{l}\text { Ex-Ante Incentive } \\
\text { Female }\end{array}$} & \multicolumn{2}{|c|}{ Whole Sample } & \multirow{2}{*}{$\begin{array}{c}\begin{array}{c}\text { App. Score } \\
\text { Exlcuded }\end{array} \\
\text { Repayment }\end{array}$} & \multirow{2}{*}{$\begin{array}{c}\text { Before } \\
\text { May } 2009 \\
\text { Repayment }\end{array}$} \\
\hline & Approval & Repayment & & \\
\hline & $\begin{array}{c}0.041 \\
(0.113)\end{array}$ & $\begin{array}{c}0.098 \\
(0.104)\end{array}$ & $\begin{array}{l}0.088 \\
(0.107)\end{array}$ & $\begin{array}{c}0.147 \\
(0.113)\end{array}$ \\
\hline Age & $\begin{array}{c}0.001 \\
(0.005)\end{array}$ & $\begin{array}{l}0.003 \\
(0.005)\end{array}$ & $\begin{array}{c}0.004 \\
(0.005)\end{array}$ & $\begin{array}{c}0.002 \\
(0.006)\end{array}$ \\
\hline High School Education & $\begin{array}{c}0.131 \\
(0.148)\end{array}$ & $\begin{array}{l}0.022 \\
(0.164)\end{array}$ & $\begin{array}{l}-0.005 \\
(0.169)\end{array}$ & $\begin{array}{l}-0.008 \\
(0.173)\end{array}$ \\
\hline Salary Earner & $\begin{array}{c}0.029 \\
(0.110)\end{array}$ & $\begin{array}{l}-0.117 \\
(0.113)\end{array}$ & $\begin{array}{l}-0.086 \\
(0.116)\end{array}$ & $\begin{array}{l}-0.106 \\
(0.133)\end{array}$ \\
\hline $\begin{array}{l}\text { Disposable Income } \\
\text { (Thousands of Rand) }\end{array}$ & $\begin{array}{c}0.034 \\
(0.057)\end{array}$ & $\begin{array}{l}0.028 \\
(0.059)\end{array}$ & $\begin{array}{l}0.037 \\
(0.061)\end{array}$ & $\begin{array}{c}0.023 \\
(0.069)\end{array}$ \\
\hline Application Score & $\begin{array}{c}0.000 \\
(0.000)\end{array}$ & $\begin{array}{c}-0.001^{* * *} \\
(0.000)\end{array}$ & - & $\begin{array}{c}0.002 \\
(0.004)\end{array}$ \\
\hline ITC Score & $\begin{array}{c}0.002 \\
(0.001)\end{array}$ & $\begin{array}{l}0.000 \\
(0.001)\end{array}$ & $\begin{array}{l}0.000 \\
(0.001)\end{array}$ & $\begin{array}{l}0.000 \\
(0.001)\end{array}$ \\
\hline ITC Score Missing & $\begin{array}{c}1.197 \\
(0.893)\end{array}$ & $\begin{array}{l}-0.116 \\
(0.895)\end{array}$ & $\begin{array}{l}-0.276 \\
(0.922)\end{array}$ & $\begin{array}{l}-0.077 \\
(0.935)\end{array}$ \\
\hline $\begin{array}{l}\text { Requested Amount } \\
\text { (Thousands of Rand) }\end{array}$ & $\begin{array}{c}0.010 \\
(0.011)\end{array}$ & $\begin{array}{c}-0.027^{*} \\
(0.016)\end{array}$ & $\begin{array}{l}-0.026 \\
(0.016)\end{array}$ & $\begin{array}{l}-0.020 \\
(0.021)\end{array}$ \\
\hline $\begin{array}{l}\text { Requested Term } \\
\text { (Months) }\end{array}$ & $\begin{array}{l}-0.013 \\
(0.015)\end{array}$ & $\begin{array}{l}0.014 \\
(0.017)\end{array}$ & $\begin{array}{l}0.010 \\
(0.018)\end{array}$ & $\begin{array}{l}0.012 \\
(0.019)\end{array}$ \\
\hline Government Worker & $\begin{array}{l}-0.389 \\
(0.266)\end{array}$ & $\begin{array}{l}0.103 \\
(0.257)\end{array}$ & $\begin{array}{l}0.023 \\
(0.264)\end{array}$ & $\begin{array}{c}0.115 \\
(0.273)\end{array}$ \\
\hline Cleaner/Builder/Miner & $\begin{array}{l}-0.094 \\
(0.207)\end{array}$ & $\begin{array}{l}0.098 \\
(0.211)\end{array}$ & $\begin{array}{c}0.028 \\
(0.217)\end{array}$ & $\begin{array}{l}0.027 \\
(0.225)\end{array}$ \\
\hline Security/Mining/Transport & $\begin{array}{l}-0.330 \\
(0.226)\end{array}$ & $\begin{array}{l}-0.321 \\
(0.251)\end{array}$ & $\begin{array}{l}-0.450^{*} \\
(0.255)\end{array}$ & $\begin{array}{l}-0.355 \\
(0.275)\end{array}$ \\
\hline Retail Worker & $\begin{array}{l}-0.212 \\
(0.203)\end{array}$ & $\begin{array}{l}-0.105 \\
(0.220)\end{array}$ & $\begin{array}{l}-0.166 \\
(0.226)\end{array}$ & $\begin{array}{l}-0.129 \\
(0.231)\end{array}$ \\
\hline IT / Financial Woker & $\begin{array}{c}-0.570^{* *} \\
(0.279)\end{array}$ & $\begin{array}{l}0.495 \\
(0.533)\end{array}$ & $\begin{array}{l}0.445 \\
(0.550)\end{array}$ & $\begin{array}{c}0.427 \\
(0.562)\end{array}$ \\
\hline Agriculture/Manufacturing & $\begin{array}{l}-0.222 \\
-0.187\end{array}$ & $\begin{array}{l}-0.168 \\
-0.222\end{array}$ & $\begin{array}{l}-0.214 \\
-0.229\end{array}$ & $\begin{array}{l}-0.199 \\
-0.234\end{array}$ \\
\hline Constant & $\begin{array}{l}-0.547 \\
(0.923)\end{array}$ & $\begin{array}{c}0.642 \\
(0.932) \\
\end{array}$ & $\begin{array}{c}0.692 \\
(0.962) \\
\end{array}$ & $\begin{array}{c}0.348 \\
(1.059) \\
\end{array}$ \\
\hline $\begin{array}{l}F \text {-test of joint significance } \\
p \text {-value of } F \text {-test }\end{array}$ & $\begin{array}{l}0.810 \\
0.669\end{array}$ & $\begin{array}{l}1.640 \\
0.077^{*}\end{array}$ & $\begin{array}{l}1.150 \\
0.326\end{array}$ & $\begin{array}{l}0.990 \\
0.478\end{array}$ \\
\hline$N$ & 123 & 120 & 120 & 108 \\
\hline
\end{tabular}


We also find evidence that referred clients are more likely to be approved for a loan. Approval rate for clients off-the-street is around $23 \%$, but for clients referred through the Refer-A-Friend program the approval rate is around $55 \%$. We will argue below that referrers were not successful in selecting on repayment type. The observation that referred clients are more likely to be approved is, therefore, consistent with two interpretations: i) peers know which of their friends are creditworthy, but this information duplicates information already held by the lender; and ii) peers have correlated credit scores and, because the referrers were all approved borrowers, their peers are more likely to be approved than an average client. ${ }^{25}$ These two possibilities make it hard to give a causal interpretation to the correlation.

Table 4: The Impact of Ex-Ante Treatment Group on Referred Characteristics

\begin{tabular}{lcc}
\hline \multirow{2}{*}{ Dep Var } & \multicolumn{2}{c}{ No Controls } \\
& Relative & Work \\
\cline { 2 - 3 } Ex-ante & & \\
Repayment Incenti & $-0.095^{*}$ & 0.051 \\
& $(0.043)$ & $(0.046)$ \\
Mean & 0.271 & 0.656 \\
$\mathrm{~N}$ & 428 & 428 \\
\hline \hline
\end{tabular}

Each column represents a separate OLS regression. Standard errors in parentheses.

\subsection{Measuring Repayment Performance}

We identify screening and enforcement effects by comparing the repayment performance of loans referred by referrers facing different incentives. We have four different and complementary measures of repayment performance. Each proxies for the costs a lender bears when borrowers don't repay (on time), without needing to impose additional assumptions on what the lender's cost structure actually is (since in our experience many lenders lack precise data on marginal costs of collections). First, we have an indicator variable, for all 245 referred clients, of whether or not the borrower was charged penalty interest for paying late at any time during the course of the loan. Second, we measure whether the loan was fully repaid on the date of maturity for the 240 loans that have reached maturity. Third, for those 240 loans we also calculate the proportion of principal still owed at maturity date (this value is zero for loans repaid on time, and positive for loans in arrears). Fourth, Opportunity charges off loans deemed unrecoverable and has made a

\footnotetext{
${ }^{25}$ It is also possible that the lender took into account whether the borrower was referred in making its approval decision. We find this unlikely for two reasons. First, the approval process is quite mechanical. Second, the lender was genuinely agnostic as to whether the referral system would work. This was one of the main reasons for implementing the experiment.
} 
Table 5: Key Outcome Variables: Mean Differences Across Treatment Groups

(a) Penalty Interest Charged by Lender $(\mathrm{N}=245)$

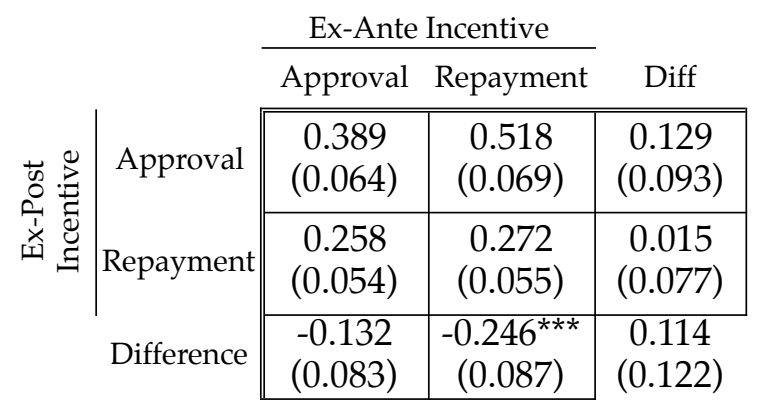

(c) Portion of Loan Value Owing at Maturity ( $\mathrm{N}=240)$

\begin{tabular}{|c|c|c|c|c|}
\hline & \multicolumn{2}{|c|}{ Ex-Ante Incentive } & \multirow[b]{2}{*}{ Diff } \\
\hline & & Approva & Repayment & \\
\hline \multirow{3}{*}{ 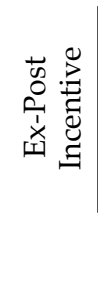 } & Approval & $\begin{array}{c}0.187 \\
(0.054)\end{array}$ & $\begin{array}{c}0.257 \\
(0.076)\end{array}$ & $\begin{array}{r}0.070 \\
(0.091)\end{array}$ \\
\hline & Repayment & $\begin{array}{c}0.076 \\
(0.039)\end{array}$ & $\begin{array}{c}0.109 \\
(0.039)\end{array}$ & $\begin{array}{c}0.033 \\
(0.055)\end{array}$ \\
\hline & Difference & $\begin{array}{l}-0.110^{*} \\
(0.066)\end{array}$ & $\begin{array}{c}-0.147^{*} \\
(0.081)\end{array}$ & $\begin{array}{c}0.037 \\
(0.108)\end{array}$ \\
\hline
\end{tabular}

(b) Positive Balance Owing at Maturity $(\mathrm{N}=240)$

\begin{tabular}{|c|c|c|c|c|}
\hline & \multicolumn{2}{|c|}{ Ex-Ante Incentive } & \multirow[b]{2}{*}{ Diff } \\
\hline & & Approval & Repayment & \\
\hline \multirow{3}{*}{ 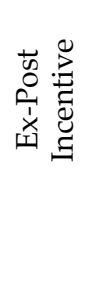 } & Approval & $\begin{array}{c}0.206 \\
(0.054)\end{array}$ & $\begin{array}{c}0.226 \\
(0.058)\end{array}$ & $\begin{array}{c}0.019 \\
(0.079)\end{array}$ \\
\hline & Repayment & $\begin{array}{c}0.095 \\
(0.037)\end{array}$ & $\begin{array}{c}0.152 \\
(0.044)\end{array}$ & $\begin{array}{c}0.056 \\
(0.058)\end{array}$ \\
\hline & Difference & $\begin{array}{l}-0.111^{*} \\
(0.064)\end{array}$ & $\begin{array}{l}-0.075 \\
(0.072)\end{array}$ & $\begin{array}{c}0.036 \\
(0.098)\end{array}$ \\
\hline
\end{tabular}

(d) Loan Charged off By Lender ( $\mathrm{N}=239)$

\begin{tabular}{|c|c|c|c|c|}
\hline & \multicolumn{2}{|c|}{ Ex-Ante Incentive } & \multirow[b]{2}{*}{ Diff } \\
\hline & & Approval & Repayment & \\
\hline \multirow{3}{*}{ 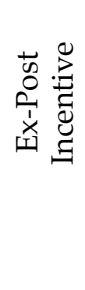 } & Approval & $\begin{array}{c}0.155 \\
(0.048)\end{array}$ & $\begin{array}{c}0.188 \\
(0.054)\end{array}$ & $\begin{array}{c}0.034 \\
(0.072)\end{array}$ \\
\hline & Repayment & $\begin{array}{c}0.047 \\
(0.027)\end{array}$ & $\begin{array}{c}0.092 \\
(0.036)\end{array}$ & $\begin{array}{c}0.045 \\
(0.045)\end{array}$ \\
\hline & Difference & $\begin{array}{c}-0.108^{* *} \\
(0.054)\end{array}$ & $\begin{array}{c}-0.096 \\
(0.063)\end{array}$ & $\begin{array}{c}0.011 \\
(0.085)\end{array}$ \\
\hline
\end{tabular}

${ }^{* * *} \Rightarrow p<0.01,{ }^{* *} \Rightarrow p<0.05,{ }^{*} \Rightarrow p<0.1$. Penalty interest is charged by the lender if a borrower is late in making an expected payment. A loan is charged off if the lender deems that there is no probability that it will be repaid. Standard errors in parentheses and $p$-values in square brackets. $p$-values are for a $\chi^{2}$-test of the hypothesis that the difference in differences is equal to zero. Ex-Ante incentive is the incentive that the referrer faced when choosing a friend to refer. Ex-Post incentive is the incentive that the referrer faced after the loan had been approved. Approval implies the loan had to be approved in order to earn the bonus and repayment implies the loan had to be repaid in order to earn the bonus.

chargeoff decision (yes or no) on all but one of the 240 loans that have reached maturity as of this writing. ${ }^{26}$

Each panel in Table 5 shows the mean of these four loan performance measures, organized by treatment groups. It also shows the difference in means holding either the ex-ante or ex-post incentive fixed. These differences are our key results. Relating these back to Section 4.2 the right most cell in the top row of each table gives $S(A)$, the right most cell in the second row gives $S(R)$ the bottom cell in the first column gives $N(a)$ and the second column gives $N(r)$. Finally, the bottom right cell in each table gives $|S(R)-S(A)|$.

\footnotetext{
${ }^{26}$ The results do not change qualitatively if we arbitrarily assign this loan as being charged off or not.
} 


\subsection{Enforcement Effects}

Table 5 provides eight estimates of the peer enforcement effect, two for each measure of default. The bottom cell in the first column of each sub-table shows an estimate of $N(a)$ and the bottom cell in the second column shows an estimate of $N(r)$. The point estimate for each of the eight differences is negative, suggesting that adding the ex-post repayment incentive decreases the incidence of default. Five of the eight estimates are statistically significant from zero, despite our small sample.

In each case the implied magnitude of the enforcement effect is large; e.g., an 11 percentage point reduction in chargeoff likelihood, on a base of $16 \%$. The size of the impacts is also large given the size of the bonus (R100) and the average loan size. It seems unlikely that these results could be driven by referrers transferring R100 to the referred to encourage repayment. In all, the results suggest that small referral incentive create social pressure that lead to large reductions in default.

It is interesting to ask how the size of the effect compares to the impact of an incentive given directly to the borrower - rather than to a peer. We have one bit of evidence from a similar context. Karlan and Zinman (2009) conducted a dynamic incentive experiment with a similar, although much larger, South African lender in 2004. That intervention is somewhat different in that the dynamic incentive did not come in the form of a cash bonus, but rather in the form of a reduced rate on a future loan. On average, the dynamic incentive reduced the interest rate on a future loan by $3.85 \%$ and led to a roughly $2.5 \%$ point increase in likelihood that the current loan was paid on time. This result suggests that to have a similar impact as our study, a direct incentive would need to be very large - in the order of a 12 percentage point reduction in the interest rate (effectively making the interest rate on the next loan zero). This again suggests that at least part of the enforcement effect in our experiment reflects social pressure, rather than simply the transfer of cash from the referrer to the borrower.

\subsection{Selection Effects}

Table 5 also provides eight estimates of the [reduced-form] peer selection effect, two for each measure of default. Relating these back to Section 4.2, the rightmost cell in the top row of each table gives $S(A)$, and the rightmost cell in the second row gives $S(R)$. Each of the eight point estimates is statistically insignificant and positive, so there is no evidence that a small referral incentive induces screening on repayment type that reduces default. In fact, if we take the point estimates seriously they imply negative selection on repayment type. This outcome is consistent with our model if there is strong intentional positive selection on malleability. As discussed in Section 4.3 , this could lead to the crowding out of the incentive to select on repayment type.

The bottom-right cell in each panel of Table 5 estimates the difference-in-differences (DD) across the two different estimates of the referral incentive effects on default rates. Recall from Section 4 that if $S(A)=S(R)$ we can rule out selection on malleability. A zero estimate of the DD 
indicates that malleability is uncorrelated with ex-ante repayment type. And indeed none of the four estimates is significantly different than zero. This suggests that, in our setting, selection on malleability and the comparability problem do not loom large. It bears emphasizing, however, that these are very imprecisely estimated zeros: each of the four confidence intervals includes economically large selection on malleability.

\subsection{Estimates of Whether Referrers Have Information}

The DD estimate and the estimates of the selection effect are also relevant to determining whether referrers have information. In Section (6.1) we argued that $E(\lambda \mid r)>E(\lambda \mid a)$. This assumption, following the analysis of Section 4.4, in combination with the findings above that $S(A)=0$ and $S(R)-S(A)=0$, suggest that referrers have no useful information for the lender (again subject to the above mentioned caveats on the distribution of repayment types and our wide confidence intervals).

\subsection{Improving Precision and Checking Robustness}

Under the assumption that malleability is uncorrelated with repayment type, which is born out by the above DD estimates, our model implies that we can estimate the extent of peer enforcement and selection with greater precision, using regressions that pool across all four treatment arms:

$$
y_{i}=\alpha+\beta^{1} \text { enforce }_{i}+\beta^{2} \text { select }_{i}+\epsilon_{i}
$$

where $y_{i}$ is one of the four measures of default, enforce $i$ is an indicator with value 1 if client $i$ was referred by someone with the ex-post repayment incentive, and select $t_{i}$ is an indicator with value 1 if the client was referred by someone with the ex-ante repayment incentive. Results from this regression (without controls) are presented in Table 6 . For each of the four outcome measures we see a large and statistically significant reduction in default associated with the enforcement incentive, and a smaller and statistically insignificant increase in default coming from the selection incentive. These results sharpen the key inferences from the means comparisons in Table 5: there is a large enforcement effect, and no (or a perverse) selection effect.

Appendix A shows that these results are robust to various specifications that control for the baseline characteristics of borrowers or referrers.

\section{Alternative Explanations}

In this section we discuss alternative interpretations of the results. 
Table 6: Pooled Impact of Selection and Enforcement Treatments on Key Outcome Variables: OLS Without Controls

\begin{tabular}{ccccc}
\hline $\begin{array}{c}\text { Outcome } \\
\text { Measure }\end{array}$ & $\begin{array}{c}\text { Penalty } \\
\text { Interest }\end{array}$ & $\begin{array}{c}\text { Not Paid } \\
\text { on Time }\end{array}$ & $\begin{array}{c}\text { Portion } \\
\text { Owing }\end{array}$ & $\begin{array}{c}\text { Loan } \\
\text { Charged } \\
\text { Off }\end{array}$ \\
\cline { 2 - 5 } Enforcement & $\begin{array}{c}-0.188^{* * *} \\
(0.061)\end{array}$ & $\begin{array}{c}-0.094^{*} \\
(0.049)\end{array}$ & $\begin{array}{c}-0.129^{* *} \\
(0.054)\end{array}$ & $\begin{array}{c}-0.100^{* *} \\
(0.042)\end{array}$ \\
Selection & 0.067 & 0.039 & 0.050 & 0.040 \\
& $\begin{array}{c}(0.060) \\
(0.047)\end{array}$ & $\begin{array}{c}(0.052) \\
(0.041)\end{array}$ \\
Constant & $\begin{array}{c}0.419^{* * *} \\
(0.054)\end{array}$ & $\begin{array}{c}0.197^{* * *} \\
(0.045)\end{array}$ & $\begin{array}{c}0.196^{* * *} \\
(0.046)\end{array}$ & $\begin{array}{c}0.149^{* * *} \\
(0.039)\end{array}$ \\
$\mathrm{N}$ & 245 & 240 & 240 & 239 \\
\hline
\end{tabular}

${ }^{* * *} \Rightarrow p<0.01,{ }^{* *} \Rightarrow p<0.05,{ }^{*} \Rightarrow p<0.1$. Penalty interest is charged by the lender if a borrower is late in making an expected payment. A loan is charged off if the lender deems that there is no probability that it will be repaid. Standard errors in parentheses. Ex-Ante incentive is the incentive that the referrer faced when choosing a friend to refer. Ex-Post incentive is the incentive that the referrer faced after the loan had been approved. Approval implies the loan had to be approved in order to earn the bonus and repayment implies the loan had to be repaid in order to earn the bonus.

\subsection{Income Effects}

In theory, the enforcement effect could be driven by side-payments from the referrer to referred that produce an income effect on loan repayment. In practice this channel seems implausible, for several reasons. First, the bonus was not paid out until after the loan was repaid, and the borrowers in our sample are liquidity constrained (as evidenced by the fact that they are borrowing at high rates). Second, even our smaller point estimates imply default reductions that seem too large (about R500 on the average loan) to be explained by a small increase in income (maximum R100). Third, as discussed above (Section 6.3), the enforcement effects here are large in comparison to effects from bonuses paid directly to the borrower.

\subsection{Signaling}

The repayment rates in Table 5 consistently show that the highest default rates occur for those clients who were in the ex-ante repayment group and moved to the ex-post approval group. In this treatment group, Opportunity phoned the referrer and told her that the bonus would no longer be paid upon repayment. It is possible that this signaled that the lender was not really interested in repayment. If this explanation is correct, then our estimate of selection conditional on being in the ex-post approval group would be biased in favor of showing no screening, while our estimate of enforcement conditional on the ex-ante repayment incentive would be biased in 
favor of finding an enforcement effect.

There are three reasons why this should not be a concern. First, recall that we can estimate the enforcement effect and selection effect without relying on the ex-ante repayment/ex-post approval arm. Second, as discussed above, it is never the case that the difference-in-differences is statistically different from zero, implying that these potentially biased estimates of selection and enforcement are not statistically different from the unbiased ones. Third, if the signaling story were correct we would anticipate that repayment rates for the referrer would also be affected. But the difference between the default rates of the "signaled" and the "un-signaled" is not significantly different from zero for any of the four default measures $(-0.060(p=0.414),-0.030$ $(p=0.473),-0.019(p=0.664)$ and $-0.006(p=0.895))$ : the data does not support the signaling story. If anything the point estimates suggest that the "signaled" were better repayers.

\subsection{Impatience}

Referrers who were assigned to the ex-ante repayment incentive were promised a bonus that would not be paid until the referrer repaid their loans. One might therefore expect fewer referrers to make a referral in this treatment group, and/or that those making referrals would be more patient (and hence be more willing to and effective at enforcing loans). Either difference could, in principle, create issues for the identification of screening effects. In practice, such issues do not loom large. First, the number of referred clients does not differ across the ex-ante treatment groups (99 in the ex-ante approval group v. 94 in the ex-ante repayment group, $p=0.516$ ). Second, if referrers in the ex-ante repayment group were more patient and this impacted on how much social pressure they placed on their referreds, then we would expect to see evidence for this in the size of the enforcement effect; i.e., estimates using the ex-ante repayment group should show larger effects As discussed above, there is no evidence for this, albeit with large confidence intervals.

\section{Conclusions}

We formalize and implement a field experiment design and show it is possible to identify peer selection and peer enforcement effects separately, even when peers select on malleablity to enforcement pressure. Novel features of the design include experimental arms without enforcement incentives (see also Gunnsteinsson (2012)), combinations of experimental arms that produce different estimates of selection and enforcement effects, and a combination that estimates the extent of selection on hidden action (malleability). We hope that our analysis of identification will pave the way for further progress in identifying interactions between hidden information and hidden action, using multi-stage experiments as well as other methods.

Our empirical results imply large peer enforcement effects. They also imply peer selection that is only partly effective: peers refer applicants who are likely to be approved, but do not end up 
producing any ex-ante information on repayment type that is useful to the lender on the margin (despite evidence suggesting that they exert at least some effort to select better repayment types).

Both theory and practice suggest that results may be different elsewhere - e.g., in settings that lack a well-functioning credit bureau, or with contracts that use larger referral bonuses - and hence our experiment is designed to be portable. Our experiment can be layered on top of any individual liability lending operation, and could be modified to work with joint liability lending. Given the implications for increased profits for the lender, the results from our demonstration could help convince lenders (and firms in other product markets) that it is worth experimenting with referral mechanisms. 


\section{References}

Ahlin, C. and R.M. Townsend, "Using repayment data to test across models of joint liability lending," Economic Journal, 2007, 117 (517), 1253-67.

Armendáriz, B., J. Morduch, and Inc ebrary, The economics of microfinance, MIT press, 2010.

Banerjee, A. and E. Duflo, "Do Firms Want to Borrow More? Testing Credit Constraints Using a Directed Lending Program," CEPR Discussion Papers, 2004.

_, - , R. Glennerster, and C. Kinnan, "The miracle of microfinance? Evidence from a randomized evaluation," Department of Economics, Massachusetts Institute of Technology (MIT) Working Paper, May, 2009.

Banerjee, A.V. and A.F. Newman, "Occupational choice and the process of development," Journal of Political Economy, 1993, 101 (2), 274-298.

_ , T. Besley, and T.W. Guinnane, "Thy neighbor's keeper: The design of a credit cooperative with theory and a test," The Quarterly Journal of Economics, 1994, 109 (2), 491.

Beaman, Lori and Jeremy Magruder, "Who gets the job referral? Evidence from a social networks experiment," The American Economic Review, 2012, 102 (7), 3574-3593.

Benabou, R. and J. Tirole, "Intrinsic and extrinsic motivation," Review of Economic Studies, 2003, $70(3), 489-520$.

Besley, T. and M. Ghatak, "Competition and incentives with motivated agents," The American economic review, 2005, 95 (3), 616-636.

- and S. Coate, "Group lending, repayment incentives and social collateral," Journal of Development Economics, 1995, 46 (1), 1-18.

Bond, P. and A.S. Rai, "Cosigned vs. group loans," Journal of Development Economics, 2008, 85 (1-2), 58-80.

Carpena, F., S. Cole, J. Shapiro, and B. Zia, "Liability Structure in Small-Scale Finance: Evidence from a Natural Experiment," World Bank Policy Research Working Paper Series, Vol, 2010.

Einav, Liran, Amy Finkelstein, Stephen P Ryan, Paul Schrimpf, and Mark R Cullen, "Selection on Moral Hazard in Health Insurance," The American Economic Review, 2013, 103 (1), 178-219.

Fischer, G., "Contract structure, risk sharing, and investment choice," London School of Economics working paper, 2010.

Galor, O. and J. Zeira, "Income distribution and macroeconomics," The Review of Economic Studies, $1993,60(1), 35-52$. 
Ghatak, M., "Group lending, local information and peer selection," Journal of Development Economics, 1999, 60 (1), 27-50.

- and T.W. Guinnane, "The economics of lending with joint liability: theory and practice1," Journal of development economics, 1999, 60 (1), 195-228.

Giné, X. and D.S. Karlan, "Group versus Individual Liability: A Field Experiment in the Philippines," 2010. Working Paper.

Giné, Xavier, Jessica Goldberg, and Dean Yang, "Credit Market Consequences of Improved Personal Identification: Field Experimental Evidence from Malawi," Technical Report, National Bureau of Economic Research 2011.

Gneezy, U. and A. Rustichini, “A Fine is a Price," The Journal of Legal Studies, 2000, 29 (1), 1-17.

Gunnsteinsson, Snaebjorn, "Information Assymmetries in Crop Insurance," 2012. mimeo.

Karlan, D. and J. Zinman, "Observing Unobservables: Identifying Information Asymmetries With a Consumer Credit Field Experiment," Econometrica, 2009, 77 (6), 1993-2008.

_ and _, "Expanding credit access: Using randomized supply decisions to estimate the impacts," Review of Financial Studies, 2010, 23 (1), 433.

_ and _ , "Microcredit in Theory and Practice: Using Randomized Credit Scoring for Impact Evaluation," Science, 2011, 332 (6035), 1278.

Klonner, S. and A.S. Rai, "Cosigners as Collateral," Journal of Development Economics, 2010.

Mel, S. De, D. McKenzie, and C. Woodruff, "Returns to Capital in Microenterprises: Evidence from a Field Experiment*," Quarterly Journal of Economics, 2008, 123 (4), 1329-1372.

Rai, A.S. and T. Sjöström, "Is Grameen lending efficient? Repayment incentives and insurance in village economies," The Review of Economic Studies, 2004, 71 (1), 217.

Stiglitz, J.E., "Peer monitoring and credit markets," The World Bank Economic Review, 1990, 4 (3), 351.

- and A. Weiss, "Credit rationing in markets with imperfect information," The American economic review, 1981, 71 (3), 393-410.

Varian, Hal, "Monitoring Agents With Other Agents," Journal of Institutional and Theoretical Economics: JITE, 1990, 146, 153-174. 


\section{A Robustness to Controls}

We now check whether the results are robust to adding controls. We start by estimating the enforcement or screening effect separately using equations of the form:

$$
y_{i}=\alpha_{i}+\beta T_{i}+\gamma X_{i}+\epsilon_{i}
$$

where $y_{i}$ is again a measure of default, $T_{i}$ is a dummy variable which takes on value 1 if $i$ is "treated", and $X_{i}$ is a set of controls for either referrer or borrower baseline characteristics (these sets of characteristics are highly collinear). When estimating the enforcement effect here, $T_{i}=1$ if the referrer was given the ex-post repayment incentive. We condition on the ex-ante incentive by running regressions separately for the samples that received the ex-ante approval incentive (Tables A.1 and A.2, Panel (a)) or the ex-ante repayment incentive (Panel (b)). When controlling for the referred's application score we include a dummy variable for whether the client came in after the change in application score procedure and also interact that term with the application score. Tables A.1 and A.2 show that adding controls does not alter the coefficients appreciably.

To test for selection effects we repeat the above exercise with $T_{i}$ being an indicator for whether the referrer was given an ex-ante repayment incentive. The results are reported in Table A.3. In Panel (a) we restrict the sample to those given the ex-post approval incentive and in Panel (b) we restrict the sample to those given the ex-post repayment incentive. For these regressions we control for referrer characteristics as the referred characteristics are endogenous. Again, the results are robust to including controls.

Finally, we again pool the data and assume that the enforcement and selection effects are independent of each other. That is we run the regression

$$
y_{i}=\alpha+\beta^{1} \text { enforce }_{i}+\beta^{2} \text { select }_{i}+\beta^{3} X_{i}+\epsilon_{i}
$$

where $X_{i}$ is a set of controls. In this case we can only control for referrer characteristics as once again the referred characteristics are endogenous. Table A.4 contains the results, which do not differ significantly from those reported in Table 6 without controls. 
Table A.1: Enforcement Effects. The Impact of Ex-Post Repayment Incentive Within Ex-Ante Treatment Group: OLS with Controls for Referrer Characteristics

(a) Ex-Ante Approval Incentive

\begin{tabular}{ccccc}
\hline & $\begin{array}{c}\text { Penalty } \\
\text { Interest }\end{array}$ & $\begin{array}{c}\text { Not Paid } \\
\text { on Time }\end{array}$ & $\begin{array}{c}\text { Portion } \\
\text { Owing }\end{array}$ & $\begin{array}{c}\text { Charged } \\
\text { Off }\end{array}$ \\
\cline { 2 - 5 } $\begin{array}{c}\text { Ex-Post } \\
\text { Approval }\end{array}$ & Left Out & Left Out & Left Out & Left Out \\
Ex-Post & -0.144 & $-0.188^{* *}$ & $-0.184^{* *}$ & $-0.166^{* *}$ \\
Repayment & $(0.097)$ & $(0.084)$ & $(0.084)$ & $(0.068)$ \\
Mean in & 0.389 & 0.206 & 0.186 & 0.155 \\
Ex-post & $(0.064)$ & $(0.054)$ & $(0.054)$ & $(0.047)$ \\
approval & & & & \\
Controls & All & All & All & All \\
N & 125 & 121 & 121 & 121 \\
\hline \hline
\end{tabular}

(b) Ex-Ante Repayment Incentive

\begin{tabular}{ccccc}
\hline & $\begin{array}{c}\text { Penalty } \\
\text { Interest }\end{array}$ & $\begin{array}{c}\text { Not Paid } \\
\text { on Time }\end{array}$ & $\begin{array}{c}\text { Portion } \\
\text { Owing }\end{array}$ & $\begin{array}{c}\text { Charged } \\
\text { Off }\end{array}$ \\
\cline { 2 - 5 } $\begin{array}{c}\text { Ex-Post } \\
\text { Approval }\end{array}$ & Left Out & Left Out & Left Out & Left Out \\
Ex-Post & $-0.208^{*}$ & -0.115 & $-0.157^{*}$ & $-0.128^{*}$ \\
Repayment & $(0.107)$ & $(0.084)$ & $(0.091)$ & $(0.076)$ \\
Mean in & 0.519 & 0.226 & 0.256 & 0.189 \\
Ex-post & $(0.069)$ & $(0.058)$ & $(0.076)$ & $(0.054)$ \\
approval & & & & \\
Controls & All & All & All & All \\
N & 120 & 117 & 117 & 117 \\
\hline \hline
\end{tabular}

${ }^{* * *} \Rightarrow p<0.01,{ }^{* *} \Rightarrow p<0.05,{ }^{*} \Rightarrow p<0.1$. Penalty interest is charged by the lender if a borrower is late in making an expected payment. A loan is charged off if the lender deems that there is no probability that it will be repaid. Standard errors in parentheses. Ex-Ante incentive is the incentive that the referrer faced when choosing a friend to refer. Ex-Post incentive is the incentive that the referrer faced after the loan had been approved. Approval implies the loan had to be approved in order to earn the bonus and repayment implies the loan had to be repaid in order to earn the bonus. Controls: Female, Age, Disposable Income, Salary Occurrence, Education, Application Score, ITC Score, Job Type, Requested Loan Amount, Requested Term, Branch, Application Month, Application year. All controls are for referrer characteristics. Categorical variables are entered as fixed effects. 
Table A.2: Enforcement Effects. The Impact of Ex-Post Repayment Incentive Within Ex-Ante Treatment Group: OLS with Controls for Referred Characteristics

(a) Ex-Ante Approval Incentive

\begin{tabular}{l}
$\begin{array}{l}\text { Penalty } \\
\text { Interest } \\
\text { on Time }\end{array}$ \\
\hline
\end{tabular}

Ex-Post
Approval

Ex-Post $\quad-0.100^{* *}-0.127^{* *}-0.120^{* *}-0.115^{* *}$

Repayment (0.034) (0.045) (0.039) (0.046)

$\begin{array}{ccccc}\text { Mean in } & 0.389 & 0.206 & 0.186 & 0.155 \\ \text { Ex-post } & (0.064) & (0.054) & (0.054) & (0.047)\end{array}$

approval

$\begin{array}{ccccc}\text { Controls } & \text { All } & \text { All } & \text { All } & \text { All } \\ \text { N } & 125 & 121 & 121 & 121\end{array}$

(b) Ex-Ante Repayment Incentive

\begin{tabular}{ccccc}
\hline & $\begin{array}{c}\text { Penalty } \\
\text { Interest }\end{array}$ & $\begin{array}{c}\text { Not Paid } \\
\text { on Time }\end{array}$ & $\begin{array}{c}\text { Portion } \\
\text { Owing }\end{array}$ & $\begin{array}{c}\text { Charged } \\
\text { Off }\end{array}$ \\
\cline { 2 - 5 } $\begin{array}{c}\text { Ex-Post } \\
\text { Approval }\end{array}$ & Left Out & Left Out & Left Out & Left Out \\
Ex-Post & $-0.312^{* *}$ & $-0.072^{*}$ & -0.066 & $-0.098^{*}$ \\
Repayment & $(0.095)$ & $(0.033)$ & $(0.040)$ & $(0.046)$ \\
$\begin{array}{c}\text { Mean in } \\
\text { Ex-post } \\
\text { approval }\end{array}$ & 0.519 & 0.226 & 0.256 & 0.189 \\
Controls & All & All & All & All \\
$\mathrm{N}$ & 120 & 119 & 119 & 118 \\
\hline \hline
\end{tabular}

${ }^{* * *} \Rightarrow p<0.01,{ }^{* *} \Rightarrow p<0.05,{ }^{*} \Rightarrow p<0.1$. Penalty interest is charged by the lender if a borrower is late in making an expected payment. A loan is charged off if the lender deems that there is no probability that it will be repaid. Standard errors in parentheses. Ex-Ante incentive is the incentive that the referrer faced when choosing a friend to refer. Ex-Post incentive is the incentive that the referrer faced after the loan had been approved. Approval implies the loan had to be approved in order to earn the bonus and repayment implies the loan had to be repaid in order to earn the bonus. Controls: Female, Age, Disposable Income, Salary Occurrence, Education, Application Score, Application Score Post May 2009, ITC Score, Job Type, Requested Loan Amount, Requested Term, Branch, Application Month, Application year. All controls are for referrer characteristics. Categorical variables are entered as fixed effects. 
Table A.3: Selection Effects. The Impact of Ex-Ante Repayment Incentive Within Ex-Post Treatment Group: OLS with Controls

(a) Ex-Post Approval Incentive

\begin{tabular}{|c|c|c|c|c|}
\hline & $\begin{array}{l}\text { Penalty } \\
\text { Interest }\end{array}$ & $\begin{array}{l}\text { Not Paid } \\
\text { on Time }\end{array}$ & $\begin{array}{l}\text { Portion } \\
\text { Owing }\end{array}$ & $\begin{array}{c}\text { Charged } \\
\text { Off }\end{array}$ \\
\hline $\begin{array}{l}\text { Ex-Ante } \\
\text { Approval }\end{array}$ & Left Out & Left Out & Left Out & Left Out \\
\hline $\begin{array}{c}\text { Ex-Ante } \\
\text { Repayment }\end{array}$ & $\begin{array}{c}0.046 \\
(0.041)\end{array}$ & $\begin{array}{c}0.046 \\
(0.035)\end{array}$ & $\begin{array}{c}0.035 \\
(0.041)\end{array}$ & $\begin{array}{c}0.027 \\
(0.031)\end{array}$ \\
\hline $\begin{array}{l}\text { Mean in } \\
\text { Ex-Ante } \\
\text { Approval }\end{array}$ & $\begin{array}{c}0.389 \\
(0.064)\end{array}$ & $\begin{array}{c}0.206 \\
(0.054)\end{array}$ & $\begin{array}{c}0.186 \\
(0.054)\end{array}$ & $\begin{array}{c}0.155 \\
(0.047)\end{array}$ \\
\hline Controls & All & All & All & All \\
\hline $\mathrm{N}$ & 113 & 111 & 111 & 111 \\
\hline
\end{tabular}

(b) Ex-Post Repayment Incentive

\begin{tabular}{|c|c|c|c|c|}
\hline & $\begin{array}{l}\text { Penalty } \\
\text { Interest }\end{array}$ & $\begin{array}{c}\text { Not Paid } \\
\text { on Time }\end{array}$ & $\begin{array}{l}\text { Portion } \\
\text { Owing }\end{array}$ & $\begin{array}{c}\text { Charged } \\
\text { Off }\end{array}$ \\
\hline $\begin{array}{l}\text { Ex-Ante } \\
\text { Approval }\end{array}$ & Left Out & Left Out & Left Out & Left Out \\
\hline $\begin{array}{c}\text { Ex-Ante } \\
\text { Repayment }\end{array}$ & $\begin{array}{c}0.007 \\
(0.100)\end{array}$ & $\begin{array}{c}0.009 \\
(0.080)\end{array}$ & $\begin{array}{c}0.018 \\
(0.075)\end{array}$ & $\begin{array}{c}0.028 \\
(0.063)\end{array}$ \\
\hline $\begin{array}{l}\text { Mean in } \\
\text { Ex-Ante } \\
\text { Approval }\end{array}$ & $\begin{array}{c}0.258 \\
(0.054)\end{array}$ & $\begin{array}{c}0.095 \\
(0.037)\end{array}$ & $\begin{array}{c}0.076 \\
(0.039)\end{array}$ & $\begin{array}{c}0.047 \\
(0.027)\end{array}$ \\
\hline Controls & All & All & All & All \\
\hline $\mathrm{N}$ & 132 & 129 & 129 & 128 \\
\hline
\end{tabular}

${ }^{* * *} \Rightarrow p<0.01,{ }^{* *} \Rightarrow p<0.05,{ }^{*} \Rightarrow p<0.1$. Penalty interest is charged by the lender if a borrower is late in making an expected payment. A loan is charged off if the lender deems that there is no probability that it will be repaid. Standard errors in parentheses. Ex-Ante incentive is the incentive that the referrer faced when choosing a friend to refer. Ex-Post incentive is the incentive that the referrer faced after the loan had been approved. Approval implies the loan had to be approved in order to earn the bonus and repayment implies the loan had to be repaid in order to earn the bonus. Controls: Female, Age, Disposable Income, Salary Occurrence, Education, Application Score, Job Type, Requested Loan Amount, Requested Term, Branch, Application Month, Application year. All controls are for referrer characteristics. Categorical variables are entered as fixed effects. 
Table A.4: Pooled Impact of Selection and Enforcement Treatments on Key Outcome Variables: OLS With Controls (same as Table 6 but with controls)

\begin{tabular}{ccccc}
\hline $\begin{array}{c}\text { Outcome } \\
\text { Measure }\end{array}$ & $\begin{array}{c}\text { Penalty } \\
\text { Interest }\end{array}$ & $\begin{array}{c}\text { Not Paid } \\
\text { on Time }\end{array}$ & $\begin{array}{c}\text { Portion } \\
\text { Owing }\end{array}$ & $\begin{array}{c}\text { Loan } \\
\text { Charged } \\
\text { Off }\end{array}$ \\
\cline { 2 - 5 } Enforcement & $\begin{array}{c}-0.168^{* * *} \\
(0.065)\end{array}$ & $\begin{array}{c}-0.117^{* *} \\
(0.055)\end{array}$ & $\begin{array}{c}-0.130^{* *} \\
(0.054)\end{array}$ & $\begin{array}{c}-0.109^{* *} \\
(0.047)\end{array}$ \\
Selection & -0.009 & 0.021 & 0.018 & 0.032 \\
& $(0.074)$ & $(0.061)$ & $(0.062)$ & $(0.053)$ \\
Mean in & 0.389 & 0.206 & 0.186 & 0.155 \\
Left Out & $(0.064)$ & $(0.054)$ & $(0.054)$ & $(0.047)$ \\
Controls & All & All & All & All \\
$\mathrm{N}$ & 245 & 240 & 240 & 239 \\
\hline \hline
\end{tabular}

${ }^{* * *} \Rightarrow p<0.01,{ }^{* *} \Rightarrow p<0.05,{ }^{*} \Rightarrow p<0.1$. Penalty interest is charged by the lender if a borrower is late in making an expected payment. A loan is charged off if the lender deems that there is no probability that it will be repaid. Standard errors in parentheses. Ex-Ante incentive is the incentive that the referrer faced when choosing a friend to refer. Ex-Post incentive is the incentive that the referrer faced after the loan had been approved. Approval implies the loan had to be approved in order to earn the bonus and repayment implies the loan had to be repaid in order to earn the bonus. Controls: Female, Age, Disposable Income, Salary Occurrence, Education, Application Score, ITC score, Job Type, Requested Loan Amount, Requested Term, Branch, Application Month, Application year. All controls are for referrer characteristics. Categorical variables are entered as fixed effects. 